\title{
Drivers of ant composition, richness, and trophic guilds in Neotropical iron ore cavities
}

\author{
Rodrigo A. Castro-Souza (D) 1,2, Thais G. Pellegrini (D) ${ }^{1,3^{*}}$, Marconi Souza-Silva (D) 1,2, \\ and Rodrigo L. Ferreira (iD) ${ }^{1,2}$ \\ ${ }^{1}$ Centro de Estudos em Biologia Subterrânea, Setor de Zoologia Geral, Departamento de Biologia, Universidade Federal de Lavras, \\ CEP 37200-000, Lavras, Minas Gerais, Brasil \\ ${ }^{2}$ Programa de Pós-Graduação em Ecologia Aplicada, Departamento de Biologia, Universidade Federal de Lavras, Cx Postal 3037, Campus Universitário, \\ CEP 37200-000, Lavras, Minas Gerais, Brasil \\ ${ }^{3}$ Programa de Pós-Graduação em Entomologia, Departamento de Entomologia, Universidade Federal de Lavras, Cx Postal 3037, Campus Universitário, \\ CEP 37200-000, Lavras, Minas Gerais, Brasil
}

\begin{abstract}
Subterranean habitats may be considered limiting for animal colonization, especially for ants, due to permanent darkness and mainly because of oligotrophic conditions. While not as deep as limestone caves, iron ore caves and other subterranean habitats may be more available for colonization because of their shallower depth. We use the richness and composition of ants to assess how differences in habitat structure affect the biodiversity and ecosystem function between cavities and surrounding epigean landscapes. We predicted that the distribution of ants would be different because of the variation in habitat structure and cavity conditions may act as a filter for colonization by ants. A high diversity of ants was found in the 20 sampled cavities ( 26 species), and most of them were grouped in the generalist trophic guilds. The distribution of ants occurred independently of the type of cavity to which they are associated (caves, impacted caves and mines). Significant differences were observed in ant richness between epigean and cavities habitats, with lower average richness in cavities. The physical attributes of the cavities did not influence richness, mainly because cavity use by ants can usually be explained by their opportunistic habits and generalist lifestyle. Ants can participate directly in the cavities assemblage, playing roles in species composition and trophic functionality, due to the lower use restriction.
\end{abstract}

Keywords: $\quad$ cave, Myrmecofauna, Formicidae, Generalists, iron ore, Brazil

Received 10 June 2019; Revised 7 November 2019; Accepted 8 November 2019

Citation: Castro-Souza R.A., Pellegrini T.G., Souza-Silva M. and Ferreira R.L., 2019. Drivers of ant composition, richness, and trophic guilds in Neotropical iron ore cavities. International Journal of Speleology, 48 (3), 279-293. Tampa, FL (USA) ISSN 0392-6672

https://doi.org/10.5038/1827-806X.48.3.2270

\section{INTRODUCTION}

Historically, studies of subterranean fauna have mainly focused on carbonate caves, probably due to their greater abundance and extent all over the world (Culver \& Pipan, 2019), and this was also true for Brazil (Pinto Da Rocha, 1995; Souza-Silva et al., 2011). However, in the last 10 years the interest in iron ore caves in Brazil has been increasing, primarily due to speleological studies required for the environmental licensing process for any kind of economic venture (Normative Instruction N. 02/2009 - Cecav, 2017). While this requirement has resulted in much research on these habitats, ironically, such systems remain the most threatened in Brazil (Ferreira et al., 2018, Mammola et al., 2019). Cave habitats threats include habitat loss, biodiversity loss, and contamination and alteration of aquifer recharge capacity (Toy et al., 2001; Carmo, 2010; Piló et al., 2015; Souza-Silva et al., 2015; Jaffé et al., 2018).

Iron ore caves are usually associated with a surficial ferruginous breccia known as "canga", which consists of fragments of rocks originated from erosional processes over the Precambrian iron-formation and hard hematite cemented by limonite (Simmons, 1960; Pomerene, 1964). The canga is extremely resistant to both chemical alteration and mechanical weathering process (Dorr, 1973). Due to this, iron ore natural caves are usually small linear-trending passageways and close to the surface (Auler et al., 2014; Piló et al., 2015). The process evolved in the canga formation also permits the existence of an extensive network 
of small channels connecting caves to the surface environment (Piló et al., 2015, Ferreira et al., 2018). Hence, these channels allow greater connectivity among such environments, and the caves provide many microhabitats available for colonization by a variety of invertebrates (Ferreira, 2005; Ferreira et al., 2015). Therefore, the subterranean fauna in iron ore caves usually has a higher species richness when compared to caves with comparable dimensions in other lithologies (Souza-Silva et al., 2011; Ferreira et al., 2015). Holes and linear conduits for mineral research, excavated by mining companies for gold prospection that were abandoned, are also present in some Brazilian iron ore landscapes (Pierre, 2011). Such artificial subterranean habitats share some features with natural caves and offer niches for colonization by cave invertebrates (Bernardi et al., 2011).

Among the invertebrate groups occurring in caves, ants have been frequently documented in both Brazil (Ferreira, 2000; Dáttilo et al., 2010; Dáttilo et al., 2012, Ferreira, 2019) and in the world (Wilson, 1962; Tinaut \& Lopez, 2001; Roncin \& Deharveng, 2003; Moulds, 2006; Batucan \& Nuñeza, 2013; Figueras \& Nuñeza, 2013; Wynne \& Voyles, 2013; Dejean et al., 2015; Pape, 2016; Naka \& Maruyama, 2018). Some ant species have characteristics that favor life in subterranean environments, especially hypogaeic foraging species, which have a great affinity for underground environments and can easily penetrate into deep zones of some caves (Pape, 2016), where there is a stable moisture-saturated atmosphere (Howarth, 1980; Howarth, 1983). Besides their use of pheromones for navigation, ants have a metapleural gland that secretes antimicrobial substances (Poulsen et al., 2006; Beattie, 2010). This affords them protection from bacteria and fungi that, despite their occurrence in all environments, are particularly abundant in caves. The variability of foraging strategies among ant species often results in their opportunistic resource utilization in both epigean and hypogean environments (Wilson, 1976; Silva \& Silvestre, 2004; Tinaut \& Lopez, 2001). Such traits may represent pre-adaptations to subterranean habitats, including the absence of light, high moisture and oligotrophy (Howarth, 1983; Culver, 1982; Mammola, 2019).

Guild separation simplifies the community and can facilitate understanding of ecological patterns (Farias \& Jaksic, 2006). Since ant guilds are frequently assumed to reflect species function (Silva \& Brandão, 2010), this kind of grouping can facilitate the understanding of the affinity of the ants for caves. We assume that the predominant use of caves by highly specific guilds would indicate a strong association with caves. However, studies focused on the subterranean characteristics and guilds that determine ant occurrence in caves are scarce, particularly in Brazilian iron ore systems (Ferreira, 2000; Dáttilo et al., 2010; Dáttilo et al., 2012).

The present study aimed to evaluate how some environmental factors of iron ore caves and other subterranean habitats (altitude, length, slope, area, volume, number and size of entrances) may influence the presence and composition of ants using these habitats. We also compared ant biodiversity patterns in the subterranean with the adjacent epigean. Moreover, we verified which epigean ant guilds are more prone to use iron ore caves and mines.

\section{MATERIALS AND METHODS}

\section{Study area}

We conducted the study in one of the main iron ore deposits in Brazil, the Iron Quadrangle district, located in the central-south region of the state of Minas Gerais, from 1500 to $1800 \mathrm{~m}$ above sea level. The climate is moist with a dry winter and a hot summer (Cwa) according to Köppen-Geiger (Alvares et al., 2013). The surrounding vegetation is dominated by a grassland habitat with sparse shrubs, regionally known as "rupestrian fields" (Santos, 2013). The main phytophysiognomy in the area is the metalophilic Savannah (Schaefer et al., 2015). The region has an average precipitation of $116.5 \mathrm{~mm}$. We used climate data collected at the São João del Rei-A514 weather station, from January 2010 to January to 2019 (Inmet, 2015, Morueta-Holme et al., 2018).

We sampled 20 iron ore cavities and adjacent surface habitats (corresponding to the cavity length) in the municipality of Mariana (Minas Gerais, Brazil), in a region locally known as Gogo (Fig. 1A-C). Among these cavities seven are natural (caves), we separated the other 13 cavities according to their historical use. Eight are impacted caves (natural caves excavated by gold miners using manual tools for extracting gold in quartz veins in the $18^{\text {th }}$ century, and characterized by branched conduits and breakdown covering most of

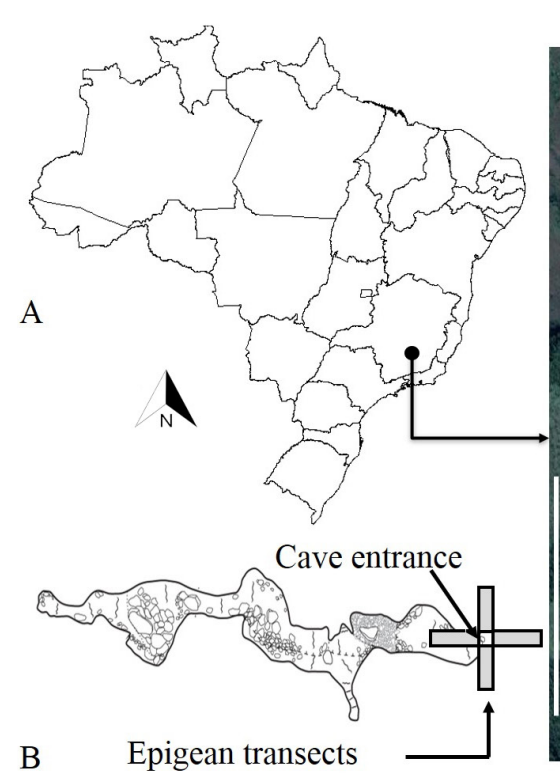

Gogo region at Mariana municipality

Fig. 1. Mariana municipality at Minas Gerais state, southeastern Brazil (A), a drawing of the transects delimitation in the epigean environment $(B)$ and distribution of iron ore caves in the Gogo region $(C)$. Red squares $=$ Caves; green squares $=$ Impacted Caves; white triangles $=$ Mines . 
the cave floor) and five are mines (linear conduits for mineral research, excavated by mining companies for gold prospecting; they were created after gold mining activity in the $19^{\text {th }}$ and $20^{\text {th }}$ century) (Pierre, 2011) (Table 1). We standardized the use of the term "cavity" since the term "cave" would not be appropriate for the impacted caves and the mines.

\section{Sampling ants in the hypogean and epigean environment}

We collected ants in April, June, November and December 2011, and March 2012 to characterize the hypogean myrmecofauna, from the entire area of the cavity (from the water "dripline" at the cavity entrance glossary of caving terms - nhvss.org.au/wp-content/ publications/glossary.htm), to the deeper zones of the caves). We made direct intuitive searches (Wynne et al., 2019), with special attention to microhabitats including under pieces of wood and rocks, as well as at other organic debris, walls and moist soils (SouzaSilva et al., 2011; Bento et al., 2016). We also carefully searched for ant nests and their larvae and pupae. The field team was composed of four biologists highly experienced in sampling subterranean dwellings. We used fine tweezers, brushes and alcohol, 70\% concentration, for sampling. We hand-collected a few specimens of each species. Although ant abundance data was not used in our analyses, all specimens (collected or observed - belonging to already sampled species) as well as all sampling locations, were

Table 1. Genera and trophic guilds of ants in iron ore environment of the Iron Quadrangle of Minas Gerais. Epigean (E), Hypogean (H), Cave (CA), Impacted Cave (IC), Mines (MI); following Silva and Brandão (2010) and Delabie et al. (2000).

\begin{tabular}{|c|c|c|c|c|c|c|c|c|c|}
\hline \multirow{2}{*}{ GUILDS } & \multicolumn{5}{|c|}{ RICHNESS } & \multirow{2}{*}{\multicolumn{3}{|c|}{ DESCRIPTION }} & \multirow{2}{*}{$\begin{array}{l}\text { TROPHIC } \\
\text { POSITION/ } \\
\text { FORAGING } \\
\text { TYPE } \\
\end{array}$} \\
\hline & $\mathbf{E}$ & CA & IC & MI & $\mathbf{H}$ & & & & \\
\hline \multicolumn{6}{|c|}{$\begin{array}{c}\text { Guild } 1 \text { (Large-sized epigaeic generalist } \\
\text { predators) }\end{array}$} & Body & Mandible & Eyes & \multirow{7}{*}{$\begin{array}{l}\text { Predator/ } \\
\text { epigaeic }\end{array}$} \\
\hline Anochetus sp. & 1 & 0 & 0 & 0 & 0 & \multirow{6}{*}{$>10 \mathrm{~mm}$} & \multirow{6}{*}{$\begin{array}{l}\text { Long triangular or } \\
\text { linear }\end{array}$} & \multirow{6}{*}{$\begin{array}{l}\text { Widely separated } \\
\text { and ommatidia } \\
\text { number }>10\end{array}$} & \\
\hline Ectatomma sp. & 1 & 0 & 0 & 0 & 0 & & & & \\
\hline $\begin{array}{l}\text { Odontomachus chelifer } \\
\text { (LATREILLE, 1802) }\end{array}$ & 1 & 1 & 1 & 0 & 1 & & & & \\
\hline $\begin{array}{l}\text { Odontomachus meinerti } \\
\text { FOREL, } 1905\end{array}$ & 0 & 1 & 1 & 0 & 1 & & & & \\
\hline $\begin{array}{l}\text { Pachycondyla striata } \\
\text { SMITH, } 1858\end{array}$ & 1 & 1 & 1 & 0 & 1 & & & & \\
\hline Pachycondyla sp. & 1 & 0 & 0 & 0 & 0 & & & & \\
\hline \multicolumn{6}{|c|}{$\begin{array}{c}\text { Guild } 2 \text { (Medium-sized epigaeic generalist } \\
\text { predators) }\end{array}$} & \multirow{3}{*}{$5-10 \mathrm{~mm}$} & \multirow{3}{*}{ Triangular } & \multirow{3}{*}{$\begin{array}{l}\text { Ommatidia number } \\
>10 \text { and eyes } \\
\text { placed relatively } \\
\text { high on head, away } \\
\text { from mandibles }\end{array}$} & \multirow{3}{*}{$\begin{array}{l}\text { Predator/ } \\
\text { epigaeic }\end{array}$} \\
\hline Gnamptogenys sp. & 1 & 0 & 0 & 0 & 0 & & & & \\
\hline Hylomyrma sp. & 1 & 0 & 0 & 0 & 0 & & & & \\
\hline \multicolumn{6}{|c|}{$\begin{array}{c}\text { Guild } 3 \text { (Medium-sized hypogaeic generalist } \\
\text { predators) }\end{array}$} & \multirow{3}{*}{ 5-10 mm } & \multirow{3}{*}{ Triangular } & \multirow{3}{*}{$\begin{array}{c}\text { Ommatidia number } \\
0-1, \text { reduced } \\
\text { eyes very close } \\
\text { to mandibular } \\
\text { insertion }\end{array}$} & \multirow{3}{*}{$\begin{array}{l}\text { Predator/ } \\
\text { hypogaeic }\end{array}$} \\
\hline Rogeria sp. & 1 & 0 & 0 & 0 & 0 & & & & \\
\hline Hypoponera sp2 & 1 & 0 & 0 & 0 & 0 & & & & \\
\hline \multicolumn{6}{|c|}{$\begin{array}{c}\text { Guild } 4 \text { (Hypogaeic generalist predators with } \\
\text { vestigial eyes) }\end{array}$} & \multirow{2}{*}{$\begin{array}{c}2-5 \mathrm{~mm} \\
\text { (Hypoponera) }\end{array}$} & \multirow{2}{*}{ Small triangular } & \multirow{2}{*}{$\begin{array}{c}\text { Reduced to one } \\
\text { ommatidia and very } \\
\text { close to mandibular } \\
\text { insertion }\end{array}$} & \multirow{2}{*}{$\begin{array}{c}\text { Generalist } \\
\text { foragers(?)/ } \\
\text { hypogaeic }\end{array}$} \\
\hline Hypoponera sp1, sp3 & 2 & 1 & 1 & 1 & 1 & & & & \\
\hline \multicolumn{6}{|c|}{$\begin{array}{c}\text { Guild } 5 \text { (Specialist predators living in the soil } \\
\text { superficial layers) }\end{array}$} & \multirow{2}{*}{$2-10 \mathrm{~mm}$} & \multirow{2}{*}{ Large with wide gap } & \multirow{2}{*}{$\begin{array}{c}\text { 0-1 ommatidia set } \\
\text { near mandibular } \\
\text { insertion and widely } \\
\text { separated }\end{array}$} & \multirow{2}{*}{$\begin{array}{c}\text { Specialist } \\
\text { predators / } \\
\text { hypogaeic and } \\
\text { subterranean }\end{array}$} \\
\hline Acropyga sp. & 0 & 0 & 1 & 0 & 1 & & & & \\
\hline $\begin{array}{r}\text { Guild } 6 \text { (Genera } \\
\text { Dolichoderines, Formi }\end{array}$ & : ge & nera & $\begin{array}{l}\text { lized } \\
\text { Iyrm }\end{array}$ & icin & & $\begin{array}{l}2-10 \mathrm{~mm} \text {, } \\
\text { reduced or }\end{array}$ & & & \\
\hline Carebara sp. & 1 & 0 & 1 & 0 & 1 & & & well-developed and & Omnivorous, \\
\hline $\begin{array}{l}\text { Camponotus crassus } \\
\text { MAYR, } 1862\end{array}$ & 1 & 0 & 0 & 0 & 0 & $\begin{array}{l}\text { except for } \\
\text { Myrmicinae: }\end{array}$ & Short and triangular & $\begin{array}{l}\text { widely separated } \\
\text { eyes }\end{array}$ & $\begin{array}{l}\text { granivorous / } \\
\text { epigaeic }\end{array}$ \\
\hline $\begin{array}{l}\text { Camponotus rufipes } \\
\text { (FABRICIUS, 1775) }\end{array}$ & 1 & 0 & 0 & 0 & 0 & $\begin{array}{l}\text { long legs and } \\
\text { scapes }\end{array}$ & & & \\
\hline Camponotus spp. & 4 & 0 & 0 & 0 & 0 & & & & \\
\hline Brachymyrmex spp. & 3 & 2 & 2 & 2 & 2 & & & & \\
\hline Pheidole spp. & 9 & 1 & 2 & 1 & 2 & & & & \\
\hline Linepithema spp. & 1 & 1 & 1 & 0 & 2 & & & & \\
\hline Dorymyrmex sp. & 1 & 0 & 0 & 1 & 1 & & & & \\
\hline Simopelta spp. & 1 & 2 & 1 & 0 & 2 & & & & \\
\hline Tapinoma sp. & 1 & 0 & 1 & 0 & 1 & & & & \\
\hline Wasmannia sp. & 1 & 0 & 0 & 0 & 0 & & & & \\
\hline
\end{tabular}




\begin{tabular}{|c|c|c|c|c|c|c|c|c|c|}
\hline \multicolumn{6}{|c|}{ Guild 7 (Dacetini predators) } & \multirow[b]{2}{*}{$\begin{array}{l}2-10 \mathrm{~mm} \text {, } \\
\text { divided into two } \\
\text { groups (1) and } \\
\text { (2) }\end{array}$} & \multirow{2}{*}{$\begin{array}{l}\text { (1): Very small } \\
\text { static pressure } \\
\text { or triangular to } \\
\text { elongate-triangular, } \\
\text { serial dentition, } \\
\text { maximum gap } \\
60-90^{\circ} ;(2) \text { : narrow, } \\
\text { sublinear to linear } \\
\text { and long, small } \\
\text { number of distally set } \\
\text { teeth, enlarged apical } \\
\text { teeth, maximum gap } \\
\text { at least } 170^{\circ} \text { (trap-jaw } \\
\text { mandibles) }\end{array}$} & \multirow[b]{2}{*}{$\begin{array}{l}\text { (1): } 0-1 \text { ommatidia, } \\
\text { set very close } \\
\text { to mandibular } \\
\text { insertion. }(2) \text { : } \\
\text { ommatidia number } \\
\quad>10\end{array}$} & \multirow[b]{2}{*}{$\begin{array}{l}\text { Specialist } \\
\text { predators/ } \\
\text { hypogaeic }\end{array}$} \\
\hline Strumigenys spp. & 1 & 0 & 2 & 0 & 2 & & & & \\
\hline \multicolumn{6}{|c|}{$\begin{array}{c}\text { Guild } 8 \text { (Small-sized hypogaeic generalist } \\
\text { foragers) }\end{array}$} & \multirow{2}{*}{$>2 \mathrm{~mm}$} & \multirow{2}{*}{$\begin{array}{l}\text { The smallest of all } \\
\text { ants }\end{array}$} & \multirow{2}{*}{$\begin{array}{l}2-5 \text { ommatidia or } \\
\text { vestigial eyes set } \\
\text { close to mandibular } \\
\text { insertion }\end{array}$} & \multirow{2}{*}{$\begin{array}{l}\text { Omnivorous(?)/ } \\
\text { hypogaeic; few } \\
\text { studied }\end{array}$} \\
\hline Solenopsis spp. & 2 & 1 & 2 & 0 & 2 & & & & \\
\hline \multicolumn{6}{|c|}{ Guild 9 (Litter-nesting fungus-growers) } & \multirow{6}{*}{\multicolumn{3}{|c|}{$\begin{array}{l}\text { General description: cultivate a symbiotic fungus on } \\
\text { arthropod refuse and carcasses and/or dead or live plant } \\
\text { material; close to the generalized Myrmicinae in the } \\
\text { morphological space. }\end{array}$}} & \multirow{6}{*}{$\begin{array}{c}\text { Fungivorous/ } \\
\text { epigaeic, } \\
\text { hypogaeic }\end{array}$} \\
\hline Acromyrmex sp. & 1 & 0 & 0 & 0 & 0 & & & & \\
\hline Mycocepurus sp. & 1 & 0 & 0 & 0 & 0 & & & & \\
\hline Atta spp. & 2 & 2 & 2 & 2 & 2 & & & & \\
\hline Trachymyrmex sp. & 1 & 0 & 0 & 0 & 0 & & & & \\
\hline Cyphomyrmex sp. & 1 & 0 & 0 & 0 & 0 & & & & \\
\hline \multicolumn{6}{|c|}{ Guild 10 (Arboreal ants) } & \multirow{7}{*}{\multicolumn{3}{|c|}{$\begin{array}{l}\text { General description: strong relationship between ants } \\
\text { and trees, logs and organic matter may be used to obtain } \\
\text { resource for nesting. }\end{array}$}} & \multirow{7}{*}{$\begin{array}{l}\text { Omnivorous / } \\
\text { hypogaeic } \\
\text { and epigaeic } \\
\text { foraging }\end{array}$} \\
\hline Nesomyrmex sp. & 1 & 0 & 0 & 0 & 0 & & & & \\
\hline $\begin{array}{l}\text { Cephalotes pusillus (KLUG, } \\
\text { 1824) }\end{array}$ & 1 & 1 & 1 & 1 & 1 & & & & \\
\hline Cephalotes spp. & 2 & 0 & 1 & 0 & 1 & & & & \\
\hline Crematogaster sp. & 1 & 0 & 1 & 0 & 1 & & & & \\
\hline Pseudomyrmex spp. & 3 & 0 & 1 & 0 & 1 & & & & \\
\hline Procryptocerus sp. & 1 & 0 & 0 & 0 & 0 & & & & \\
\hline
\end{tabular}

plotted on maps of each cavity, providing the spatial distribution of each species within the cavities. Such methodology minimizes impacts to the cavity fauna, whereas the use of traps can significantly adversely affect some population sizes (Weinstein \& Slaney, 1995; Sharratt et al., 2000). The use of multiple methods for invertebrate cave fauna sampling is known to maximize the completeness of the survey (Wynne et al., 2019). Despite this, we opted to not use bait, since it could attract ants due to the proximity of the iron ore cavities to the surface/epigean habitats.

In order to sample the epigean fauna, we established two transects using the cavity entrance as the intersecting center point (Fig. 1B). Transect lengths and area varied. The sum of the transect lengths used per cavity were identical to each cavity length. (Fig. 1B). Epigean transects received direct intuitive searches and hand-collect prioritizing spaces under rocks, wood and leaf litter, in order to enable the comparison between the two sampling sites. Due to safety concerns, we did not apply this methodology to six cavities with entrances in extremely steep terrain, or those embedded in ditches or trenches. We did not include these cavities in the comparisons between the epigean and hypogean environments.

\section{Identification of ants and characterization of trophic guilds}

We identified the specimens to species or genus level using Baccaro (2006) and Baccaro et al. (2015) and then sorted into morphotypes. All the sampled ants are deposited in the Collection of Subterranean Invertebrates (ISLA) of the Center of Studies on Subterranean Biology (CEBS) at the Federal University of Lavras (UFLA), municipality of Lavras, state of Minas Gerais, Brazil.

We grouped the ants into trophic guilds by genus according to Silva \& Brandão (2010) and the official homepage of Brazilian ants (https:// formigasdobrasil.com/). We based the trophic guilds on body size, number of ommatidia and mandible shape. We performed measurements with the aid of an AXIO Zoom V16 - ZEISS stereomicroscope. We included to Baccaro guild separation the arboreal guild following the model proposed by Delabie et al. (2000). We obtained information on the biology of arboreal guild genera from the official homepage of Brazilian ants (https://formigasdobrasil.com/). Thus, it was possible to obtain information on feeding requirements, morphological characteristics and foraging habit according to Silva \& Brandão (2010). The names of each guild used in the current work are presented in Table 1. It is worth mentioning that the term hypogaeic used in some of the guilds separation refers to the vertical stratification of ants, as they live in the deepest soil layers (Schmidt $\&$ Solar, 2010). On the other hand, the term hypogean is used when we refer to the subterranean environment (cavities).

Recording environmental variables and parameters

The altitude and location of the cavities were determined using a Garmin Etrex Vista Hcx GPS unit 
(Datum SAD 69 zone 23K). A geologist (Ataliba Coelho) performed internal surveys in each cavity and elaborated the topographic maps. The aforementioned researcher obtained the cavities topography maps using compass, clinometers Suunto and Leica laser tape measure. The accuracy of the maps reached $5 \mathrm{D}$, based on the British Cave Research Association (BCRA) system. The topography path followed the fixed base method. The final cartography was performed in AutoCAD software, with georeferenced platform. The generated cartography also enabled the elaboration of speleometric calculations, including horizontal projection (discontinuity method), unevenness, area and estimated volume. To calculate the horizontal projection, the discontinuity principle was used. Hence, we obtained morphometric data from each cavity (length, slope, area, volume, number of entrances, position and linear extension of entrances) from the topographic maps (Table 2).

Table 2. Biotic and abiotic attributes of cavities and surroundings landscapes in Brazil, where ants were sampled. Cave (CA), Impacted Cave (IC), Mines (MI), total richness in the hypogean environment (HS), total richness in the epigean environment (ES), Environmental Stability index values (ESI), UTM coordinates (X and Y, zone 23K), horizontal projection (HP m), altitude (Alt $\mathrm{m}$ ), slope (SI), area (A), volume (V), number of entrances (NE) and sum of the entrances extension (SE). No data (ND).

\begin{tabular}{|c|c|c|c|c|c|c|c|c|c|c|c|c|c|}
\hline Cave & Type & HS & ES & ESI & $\mathbf{x}$ & $\mathbf{Y}$ & HP (m) & Alt (m) & S1 (m) & $\mathbf{A}\left(\mathbf{m}^{2}\right)$ & $\mathbf{V}\left(\mathrm{m}^{3}\right)$ & NE & SE (m) \\
\hline SPA-10 & IC & 3 & ND & 0.25 & 662584 & 7749095 & 26.50 & 829 & 1.00 & 58.90 & 48 & 6 & 14.90 \\
\hline SPA-16 & IC & 7 & 15 & 3.34 & 662455 & 7749090 & 71.00 & 890 & 4.70 & 215.00 & 236 & 6 & 4.75 \\
\hline SPB-07 & IC & 3 & 32 & 4.77 & 662194 & 7749295 & 84.60 & 914 & 0.90 & 255.00 & 352 & 2 & 2.44 \\
\hline SPB-17 & IC & 5 & 24 & 2.25 & 662446 & 7749101 & 63.00 & 898 & 1.00 & 188.00 & 249 & 6 & 7.10 \\
\hline SPB-50 & IC & 8 & ND & 1.50 & 661944 & 7749570 & 34.80 & 834 & 1.30 & 190.00 & 264 & 1 & 7.80 \\
\hline SPB-65 & IC & 3 & ND & 3.10 & 661958 & 7749546 & 168.00 & 860 & 8.00 & 860.00 & 1368 & 1 & 7.60 \\
\hline SPD-03 & IC & 5 & 24 & 2.28 & 662062 & 7749343 & 102.00 & 917 & 3.20 & 272.00 & 133 & 4 & 9.25 \\
\hline SPD-27 & IC & 2 & 19 & 1.01 & 662157 & 7749701 & 38.70 & 911 & 4.70 & 137.00 & 160 & 2 & 22.10 \\
\hline SPA-35 & MI & 2 & 8 & 2.51 & 662143 & 7749113 & 13.40 & 948 & 12.0 & 24.80 & 58 & 1 & 1.09 \\
\hline SPA-62 & MI & 4 & ND & 3.54 & 662262 & 7748999 & 46.00 & 947 & 4.40 & 46.00 & 72 & 1 & 1.33 \\
\hline SPA-63 & MI & 4 & ND & 1.45 & 662281 & 7748984 & 7.10 & 947 & 1.10 & 8.60 & 8 & 1 & 1.67 \\
\hline SPA-74 & MI & 2 & ND & 3.31 & 661658 & 7749688 & 45.00 & 923 & 2.30 & 59.30 & 74 & 1 & 1.65 \\
\hline SPC-36 & MI & 2 & 29 & 2.42 & 662174 & 7749145 & 12.40 & 936 & 9.80 & 21.20 & 62 & 1 & 1.10 \\
\hline SPA-66 & CA & 4 & 7 & 0.56 & 662153 & 7749211 & 5.60 & 941 & 0.60 & 19.40 & 9 & 2 & 5.05 \\
\hline SPB-10 & $\mathrm{CA}$ & 4 & 9 & 0.04 & 662026 & 7749294 & 13.60 & 932 & 17.0 & 76.40 & 63 & 2 & 10.2 \\
\hline SPB-12 & CA & 5 & 10 & 2.27 & 662578 & 7749076 & 11.20 & 860 & 1.20 & 48.60 & 65 & 2 & 13 \\
\hline SPB-45 & $\mathrm{CA}$ & 4 & 9 & 1.71 & 661674 & 7748887 & 20.80 & 1093 & 1.00 & 47.00 & 33 & 1 & 3.77 \\
\hline SPC-30 & $\mathrm{CA}$ & 6 & 11 & 1.96 & 662064 & 7749078 & 20.70 & 982 & 0.90 & 38.00 & 24 & 1 & 2.92 \\
\hline SPD-10 & CA & 3 & 6 & 0.67 & 662692 & 7749261 & 11.70 & 796 & 0.40 & 46.20 & 38 & 1 & 6 \\
\hline SPD-11 & $\mathrm{CA}$ & 3 & 8 & 0.57 & 662678 & 7749255 & 17.70 & 805 & 0.50 & 102.00 & 191 & 1 & 10 \\
\hline
\end{tabular}

We determined the environmental stability for each cavity using the Environmental Stability Index (ESI) (Ferreira, 2004; Bento et al., 2016; Pellegrini et al., 2016), which considers the ratio between the total length of the cavity, the width of entrances and the distance between them. This index expresses the isolation of the cavity habitat in relation to the epigean environment and is calculated according to the following formulas:

For cavities with just one entrance:

$$
E S I=\ln \left(\frac{T E}{E E}\right)
$$

where $E S I=$ environmental stability Index; $T E=$ total length of the cavity; $E E=$ entrance extension.

For cavities with more than one entrance:

$$
E S I=\frac{\ln \left(\frac{T E}{\sum E E}\right)}{\left(\frac{(E N)(A D E)}{T E}\right)}
$$

where $T E=$ total length of the cavity; $\Sigma E E=$ sum of all entrances extension; $E N=$ number of entrances;
$A D E=$ average distance between entrances measured from one reference entrance.

\section{Data analysis}

First we built a Venn diagram graphic in order to illustrate the degree of species overlap among the different types of cavities. We used the biocLite function, limma package, in the $\mathrm{R}$ 3.2.4 software (R Core Team, 2016)

In order to test species richness differences in the average richness among caves, impacted caves and mines, first we evaluated species richness data normality based on the Shapiro-Wilk test. Since data presented a normal distribution we conducted an ANOVA followed for the Tuckey-test. We used the AOV and the TukeyHSD functions, both from STATS package. To represent it visually we constructed a boxplot graphic. We conduced the analyses and graphic using the software R 3.2.4 software ( $\mathrm{R}$ Core Team, 2016).

We examined differences among caves $(\mathrm{n}=7)$, impacted caves $(n=8)$ and mines $(n=5)$ using nonmetric multidimensional scaling (nMDS) and ANOSIM (analysis of similarities) with "Jaccard" 
distance index. We performed a bootstrap average analysis to determine the level of spread within and among three groups (Clarke \& Gorley, 2015). We performed the analysis using the software Primer -7 (Clarke \& Gorley, 2015).

Moreover, we conducted a Mantel test using Bioestat 5.0 software (Ayres et al., 2007) to evaluate whether the geographical distance among cavities influenced the similarity of the hypogean myrmecofauna.

We conducted the same analyses to investigate average richness differences and compositional variation (n-MDS followed by ANOSIM) between epigean and hypogean environments. Since data presented a nonnormal distribution we conducted the non-parametric Kruskal-Wallis test, which is also appropriate for different sample size data (McCune \& Grace, 2002). We used the KRUSKAL.TEST function, from STATS package, using the software R 3.2.4 software ( $\mathrm{R}$ Core Team, 2016). We calculated the beta diversity to verify the compositional variation between the aboveground and subterranean ant fauna. The beta diversity can be obtained from species substitution (turnover) or species loss/gain (nestedness), and it is possible to access the contribution from each process through the beta diversity partitioning (Baselga \& Orme, 2012). To determine if the heterogeneity patterns among cavities are the result of spatial turnover or nestedness patterns we conducted the beta diversity partitioning. We performed this beta diversity partitioning using the BETA.MULT function, BAT package, in the $\mathrm{R}$ 3.2.4 software ( $\mathrm{R}$ Core Team, 2016). This package uses the "Sørensen" dissimilarity index to obtain species turnover and the "Jaccard" index to determine nestedness (Baselga \& Orme, 2012).

We tested if the occurrence of guilds is independent of the environment (epigean/hypogean) or of the cavity type (caves, impacted caves and mines) using chi-squared contingency table tests; CHISQ.TEST function, VEGAN package, in the R 3.2.4 software ( $R$ Core Team, 2016).

Finally we performed a generalized linear model (GLM) in order to verify the relationship between species richness with cavity type, altitude, cavity length, slope, area, volume and environmental stability, using the function GLM in the STATS package (we tested the normality by the Shapiro-Wilk test). Since we obtained nonparametric data, the error distribution with the best fit was quasi-poisson. We performed GLM analyses using the software R (R Core Team, 2016).

\section{RESULTS}

We identified a total of 59 ant morphotypes, which belong to 6 subfamilies and 30 genera sampled in the hypogean and epigean environments (Table 1). Only five morphotypes occurred in the three cavity types: the two Atta species, Carebara sp. 1, Hypoponera sp. 3 and Pheidole sp. 5 (Fig. 2).

\section{Cavity ant richness, composition and distribution patterns}

In the hypogean environment, 26 species were found overall, which belong to 5 subfamilies and 17

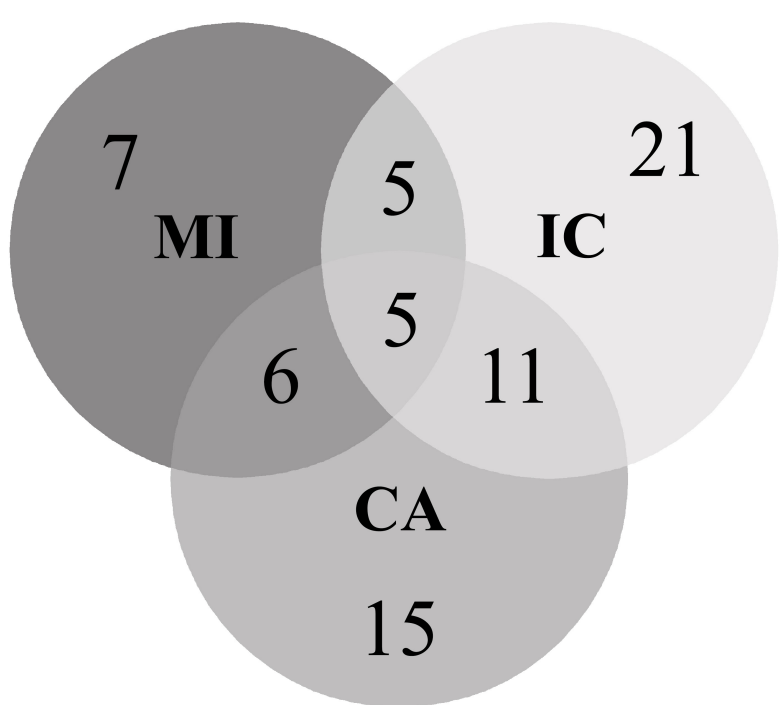

Fig. 2. Venn Diagram comparing the hypogean ant fauna found in the three cavity types. CA = Caves; IC = Impacted Caves; $\mathrm{MI}=$ Mines.

genera. Only one genus, Acropyga sp. (Formicinae) was exclusively recorded in the cavities, but it is not a troglobiotic species. In addition, six species were exclusive to the hypogean environment: Tapinoma sp. and Linepithema sp. (Dolichoderinae); Odontomachus meinerti Forel, 1905 and Simopelta sp. (Ponerinae) and two Strumigenys species (Myrmicinae). No nesting of ants was detected inside the cavities, although it was possible to observe ant worker aggregations in deeper cavity regions, regardless of the cavity type. The breakdown of species by cavity type was; 23 species in impacted caves, 13 species in caves and 8 species in mines. The list of ants collected in the hypogean environment is presented in Table 1 . The average richness was significantly different $(\mathrm{KW}=19.57$, $\mathrm{p}=0.001$ ) among impacted caves, caves and mines (Fig. 3A, Table 2).

Half of the ant species observed in this study (13 spp.) presented a single occurrence, and only one species (Carebara sp.1) occurred in more than 14 cavities (Table 3). Morphotype composition across the three groups (impacted caves, caves and mines) was not significantly distinctive (ANOSIM $\mathrm{R}=-0.047$, $\mathrm{p}=$ 0.69). Furthermore, a significant correlation was not found between similarity (morphotypes composition) and the cavity geographical distance (Mantel test, $\mathrm{p}=0.5218, \mathrm{r}=0.0236$ ).

\section{Epigean and hypogean richness, composition and diversity patterns of ants}

Fifty-three species from 29 genera and 6 subfamilies were recorded on the surface of 14 cavities (Table 3). Overall, 32 species were found only in epigean habitats. As expected, the average richness of the epigean habitat was significantly higher than in the hypogean $(\mathrm{KW}$ chi-squared $=20.313, \mathrm{p}=0.00001$ ) (Fig. 3B). Considering both epigean and hypogean environments, the following morphotypes were shared: two species of Brachymyrmex (Formicinae), two species of Atta, Carebara sp., Cephalotes pusillus, Cephalotes sp., Crematogaster sp., two species of Pheidole, Solenopsis sp. and Strumigenys sp. (Myrmicinae), Hypoponera sp., Odontomachus chelifer, 
A

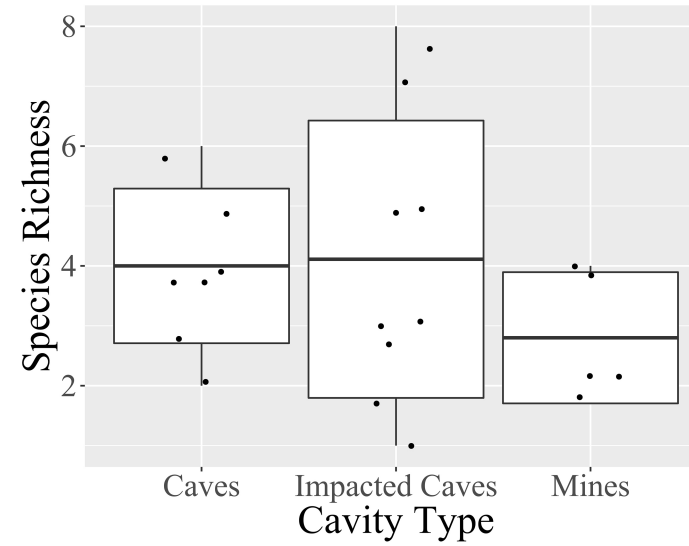

B

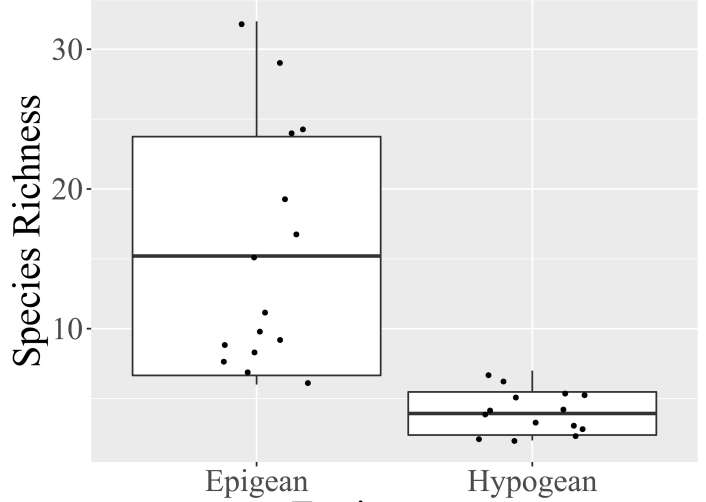

Environment

Fig. 3. Average richness of ant species in different cavity types (A) and between hypogean and epigean habitats (B) in southeast of Brazil.

Table 3. Ant species distribution between epigean and hypogean environments.

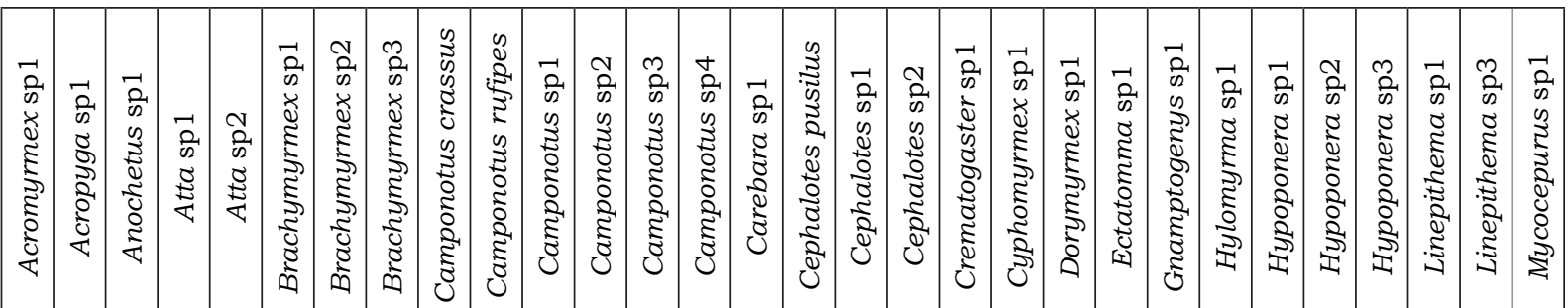

\begin{tabular}{|c|c|c|c|c|c|c|c|c|c|c|c|c|c|c|c|c|c|c|c|c|c|c|c|c|c|c|c|c|c|c|c|}
\hline \multirow{14}{*}{ 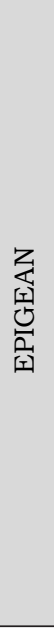 } & SPA-16 & $\mathrm{X}$ & & $\mathrm{X}$ & $\mathrm{X}$ & & & & & $\mathrm{X}$ & $\mathrm{X}$ & & & & & $X$ & $\mathrm{X}$ & & & $\mathrm{X}$ & & & & $\mathrm{X}$ & $\mathrm{X}$ & & $X$ & $\mathrm{X}$ & & & \\
\hline & SPA-35 & & & & & & & $\mathrm{x}$ & & $\mathrm{X}$ & & $\mathrm{X}$ & & & & $\mathrm{X}$ & & & & & & & & & $\mathrm{X}$ & & & & & & \\
\hline & SPA-66 & & & & & & & $\mathrm{x}$ & & & $\mathrm{X}$ & & & & & & & & & & $\mathrm{X}$ & & & & & & & & $\mathrm{X}$ & & $\mathrm{X}$ \\
\hline & SPB-07 & & & $\mathrm{x}$ & $\mathrm{X}$ & $\mathrm{X}$ & $\mathrm{X}$ & $\mathrm{X}$ & & $\mathrm{X}$ & $\mathrm{X}$ & $\mathrm{X}$ & $\mathrm{X}$ & & & $\mathrm{X}$ & $\mathrm{X}$ & $\mathrm{X}$ & & $\mathrm{X}$ & $\mathrm{X}$ & $\mathrm{X}$ & & $\mathrm{X}$ & $\mathrm{X}$ & $\mathrm{X}$ & $\mathrm{X}$ & & $\mathrm{X}$ & & $\mathrm{X}$ \\
\hline & SPB-10 & & & & & $\mathrm{X}$ & $\mathrm{X}$ & & & & $\mathrm{X}$ & & & & & $\mathrm{X}$ & $\mathrm{X}$ & & & & & & & & & & & & $\mathrm{X}$ & & \\
\hline & SPB-12 & $\mathrm{X}$ & & & $\mathrm{X}$ & & $\mathrm{X}$ & & & & & & & & & $\mathrm{X}$ & & & & $\mathrm{X}$ & $\mathrm{X}$ & $\mathrm{X}$ & & & & & & & & & $\mathrm{X}$ \\
\hline & SPB-17 & $\mathrm{X}$ & & $\mathrm{x}$ & $\mathrm{X}$ & & $\mathrm{X}$ & $\mathrm{X}$ & $\mathrm{x}$ & & $\mathrm{X}$ & & & $\mathrm{X}$ & & $\mathrm{X}$ & $\mathrm{X}$ & & & $\mathrm{X}$ & & & $\mathrm{X}$ & $\mathrm{X}$ & & $\mathrm{X}$ & & & $\mathrm{X}$ & & \\
\hline & SPB-45 & & & $\mathrm{x}$ & & & $\mathrm{X}$ & $\mathrm{x}$ & & & & & & & & $\mathrm{X}$ & & & & & $\mathrm{X}$ & & & $\mathrm{X}$ & & $\mathrm{X}$ & & & & & \\
\hline & SPC-30 & & & $\mathrm{x}$ & $\mathrm{x}$ & & $\mathrm{X}$ & $\mathrm{x}$ & & & & & & & & & $\mathrm{X}$ & & & & $\mathrm{X}$ & $\mathrm{X}$ & & & $\mathrm{X}$ & & & & & & \\
\hline & SPC-36 & & & $\mathrm{X}$ & $\mathrm{x}$ & $\mathrm{X}$ & $\mathrm{X}$ & $\mathrm{x}$ & & $\mathrm{X}$ & $\mathrm{X}$ & $\mathrm{X}$ & & & & & $\mathrm{X}$ & $\mathrm{X}$ & & $\mathrm{X}$ & $\mathrm{X}$ & & $\mathrm{X}$ & & & & & & $\mathrm{X}$ & & $\mathrm{X}$ \\
\hline & SPD-03 & & & $\mathrm{x}$ & $\mathrm{X}$ & $\mathrm{X}$ & $\mathrm{X}$ & $\mathrm{X}$ & & $\mathrm{X}$ & & $\mathrm{X}$ & & $\mathrm{X}$ & $\mathrm{X}$ & $\mathrm{X}$ & & & $\mathrm{X}$ & $\mathrm{X}$ & & $\mathrm{X}$ & & & & & & & & & $\mathrm{X}$ \\
\hline & SPD-10 & & & & & & $\mathrm{X}$ & & & & & & & & & $\mathrm{X}$ & $\mathrm{X}$ & & & $\mathrm{X}$ & & & & & & & & & & & \\
\hline & SPD-11 & & & $\mathrm{x}$ & & & & $\mathrm{x}$ & & & $\mathrm{X}$ & & & & & & $\mathrm{X}$ & & & $\mathrm{X}$ & & $\mathrm{X}$ & & & & & & & & & \\
\hline & SPD-27 & & & $\mathrm{x}$ & $\mathrm{X}$ & & $X$ & $\mathrm{X}$ & & $X$ & $X$ & & & $X$ & & $\mathrm{X}$ & & & & $\mathrm{X}$ & & & & & $X$ & & & & $\mathrm{X}$ & & \\
\hline \multirow{20}{*}{ 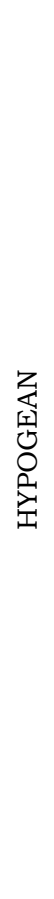 } & SPA-10 & & & & & & & $\mathrm{x}$ & & & & & & & & $\mathrm{X}$ & & & & & & & & & & & & & & & \\
\hline & SPA-16 & & & & & & & & & & & & & & & $\mathrm{X}$ & & & & & & & & & & & & $\mathrm{X}$ & $\mathrm{X}$ & & \\
\hline & SPA-35 & & & & $\mathrm{X}$ & & & & & & & & & & & & $\mathrm{X}$ & & & & & & & & & & & & & & \\
\hline & SPA-62 & & & & $\mathrm{X}$ & $\mathrm{X}$ & & & & & & & & & & $\mathrm{X}$ & & & & & & & & & & & & $\mathrm{X}$ & & & \\
\hline & SPA-63 & & & & $\mathrm{X}$ & $\mathrm{X}$ & & & & & & & & & & $\mathrm{X}$ & & & & & & $\mathrm{X}$ & & & & & & & & & \\
\hline & SPA-66 & & & & & & & & & & & & & & & $\mathrm{X}$ & & & & & & & & & & & & & & & \\
\hline & SPA-74 & & & & & & & & & & & & & & & $\mathrm{X}$ & & & & & & & & & & & & & & & \\
\hline & SPB-07 & & & & $\mathrm{X}$ & & & & & & & & & & & & & & & & & & & & & & & & & & \\
\hline & SPB-10 & & & & & $\mathrm{X}$ & & & & & & & & & & $\mathrm{X}$ & $\mathrm{X}$ & & & & & & & & & & & & & $\mathrm{X}$ & \\
\hline & SPB-12 & & & & & & $\mathrm{X}$ & & & & & & & & & & $\mathrm{X}$ & & & & & & & & & & & & & & \\
\hline & SPB-17 & & & & $\mathrm{X}$ & & & & & & & & & & & $\mathrm{X}$ & & & & & & & & & & & & & & & \\
\hline & SPB-45 & & & & & & $\mathrm{X}$ & $\mathrm{x}$ & & & & & & & & $\mathrm{X}$ & & & & & & & & & & & & & & & \\
\hline & SPB-50 & & & & $\mathrm{X}$ & & $\mathrm{X}$ & & & & & & & & & $\mathrm{X}$ & & & & & & & & & & & & & & & \\
\hline & SPB-65 & & & & & & $\mathrm{X}$ & & & & & & & & & & & & & & & & & & & & & & & & \\
\hline & SPC-30 & & & & $\mathrm{X}$ & $\mathrm{X}$ & $\mathrm{X}$ & $\mathrm{x}$ & & & & & & & & $\mathrm{X}$ & & & & & & & & & & & & $\mathrm{X}$ & & & \\
\hline & SPC-36 & & & & $\mathrm{X}$ & & & & & & & & & & & & & & & & & & & & & & & & & & \\
\hline & SPD-03 & & $\mathrm{X}$ & & & & & & & & & & & & & $\mathrm{X}$ & & & $\mathrm{X}$ & $\mathrm{X}$ & & & & & & & & & & & \\
\hline & SPD-10 & & & & & & & & & & & & & & & $\mathrm{X}$ & $\mathrm{X}$ & & & & & & & & & & & & & & \\
\hline & SPD-11 & & & & & & & $\mathrm{x}$ & & & & & & & & $\mathrm{X}$ & & & & & & & & & & & & & & & \\
\hline & SPD-27 & & & & $\mathrm{X}$ & $\mathrm{X}$ & & & & & & & & & & & & & & & & & & & & & & & & & \\
\hline
\end{tabular}




\begin{tabular}{|c|c|c|c|c|c|c|c|c|c|c|c|c|c|c|c|c|c|c|c|c|c|c|c|c|c|c|c|c|}
\hline & 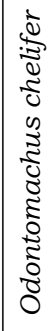 & 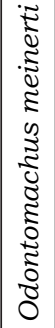 & 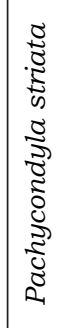 & 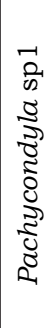 & 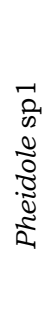 & 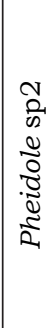 & 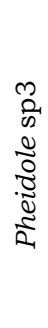 & $\begin{array}{l} \pm \\
0 \\
0 \\
0 \\
0 \\
0 \\
0 \\
\frac{0}{2} \\
\frac{1}{2}\end{array}$ & 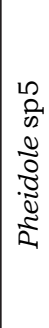 & 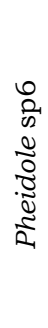 & 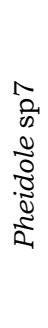 & 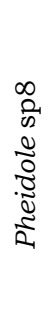 & $\begin{array}{l}0 \\
0 \\
0 \\
0 \\
\frac{0}{0} \\
-\frac{0}{0} \\
\frac{\pi}{2}\end{array}$ & 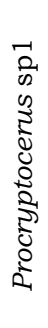 & 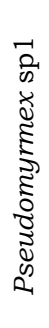 & 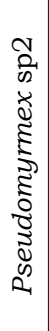 & 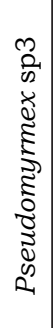 & 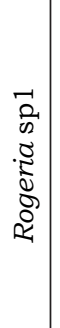 & 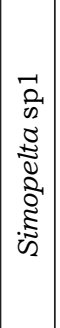 & 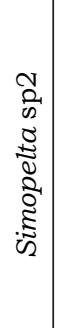 & $\begin{array}{l}\vec{a} \\
0 \\
0 \\
0 \\
0 \\
0 \\
0 \\
0 \\
0 \\
0 \\
0\end{array}$ & 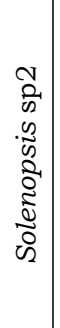 & 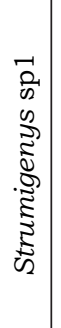 & 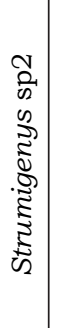 & 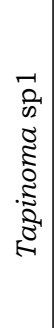 & 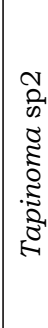 & 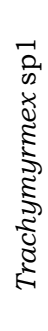 & 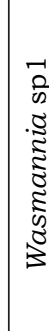 \\
\hline
\end{tabular}

\begin{tabular}{|c|c|c|c|c|c|c|c|c|c|c|c|c|c|c|c|c|c|c|c|c|c|c|c|c|c|c|c|c|c|c|}
\hline \multirow{14}{*}{ 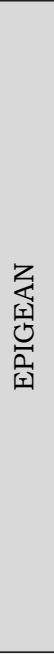 } & SPA-16 & & & & & & & $\mathrm{X}$ & & $\mathrm{X}$ & & & $\mathrm{X}$ & & & & & & & & & & & & & & & & & \\
\hline & SPA-35 & & & & & & $\mathrm{X}$ & & & $\mathrm{X}$ & & & $\mathrm{X}$ & & & & & & & & & & & & & & & & & \\
\hline & SPA-66 & & & & & $\mathrm{X}$ & & & & & & & & & & & & & & & & & & $\mathrm{X}$ & & & & & & \\
\hline & SPB-07 & & & & & & $\mathrm{X}$ & $\mathrm{X}$ & & $\mathrm{X}$ & $\mathrm{x}$ & $\mathrm{X}$ & $\mathrm{X}$ & & & & $\mathrm{x}$ & & & & & & $\mathrm{X}$ & $\mathrm{X}$ & & & $\mathrm{X}$ & & $\mathrm{X}$ & \\
\hline & SPB-10 & & & & & & $\mathrm{X}$ & & & & $\mathrm{X}$ & & & & & & & & & & & & & & & & & & & $\mathrm{X}$ \\
\hline & SPB-12 & & & & & & $\mathrm{X}$ & & & & & & $\mathrm{X}$ & & & & & & & & & & & & & & & & & \\
\hline & SPB-17 & & & & & & $\mathrm{X}$ & $X$ & & $\mathrm{X}$ & $\mathrm{X}$ & & $X$ & & & & $\mathrm{X}$ & & & $\mathrm{X}$ & & $\mathrm{X}$ & & & $\mathrm{X}$ & & & & & \\
\hline & SPB-45 & & & & $\mathrm{X}$ & & & & & & & & $\mathrm{X}$ & & & & & & & & & & & & & & & & & \\
\hline & SPC-30 & & & & & & $\mathrm{X}$ & & & & & & $\mathrm{X}$ & $\mathrm{X}$ & & & & & & & & & & & & & & & & \\
\hline & SPC-36 & $\mathrm{X}$ & & & $\mathrm{X}$ & & $\mathrm{X}$ & $\mathrm{X}$ & $\mathrm{X}$ & $\mathrm{X}$ & $\mathrm{x}$ & $\mathrm{X}$ & $\mathrm{X}$ & & & & $\mathrm{X}$ & $\mathrm{X}$ & $\mathrm{X}$ & & & & & & & & $\mathrm{X}$ & & $\mathrm{X}$ & \\
\hline & SPD-03 & & $\mathrm{X}$ & & & & $\mathrm{X}$ & $\mathrm{X}$ & $\mathrm{X}$ & & $\mathrm{x}$ & $\mathrm{X}$ & & $\mathrm{X}$ & $\mathrm{X}$ & & & $\mathrm{X}$ & & & & & & & & & & & & $\mathrm{X}$ \\
\hline & SPD-10 & & & & & & & & & $\mathrm{X}$ & & & $\mathrm{X}$ & & & & & & & & & & & & & & & & & \\
\hline & SPD-11 & & & & & & & & & & $\mathrm{X}$ & & $X$ & & & & & & & & & & & & & & & & & \\
\hline & SPD-27 & & & & & & $\mathrm{X}$ & $\mathrm{X}$ & & $\mathrm{X}$ & & $\mathrm{X}$ & $\mathrm{X}$ & & & $\mathrm{x}$ & & & & & & & & $\mathrm{X}$ & & & $\mathrm{X}$ & & & \\
\hline \multirow{20}{*}{$\begin{array}{l}\text { Z } \\
\text { 空 } \\
0 \\
0 \\
\text { 至 }\end{array}$} & SPA-10 & & & & & & & & & & & & & & & & & & & & & & & $X$ & & & & & & \\
\hline & SPA-16 & & $\mathrm{X}$ & & $\mathrm{X}$ & & & $\mathrm{X}$ & & & & & & & & & & & & & & & & $\mathrm{X}$ & & & & & & \\
\hline & SPA-35 & & & & & & & & & & & & & & & & & & & & & & & & & & & & & \\
\hline & SPA-62 & & & & & & & & & & & & & & & & & & & & & & & & & & & & & \\
\hline & SPA-63 & & & & & & & & & & & & & & & & & & & & & & & & & & & & & \\
\hline & SPA-66 & & $\mathrm{X}$ & & $\mathrm{X}$ & & & & & & & & & & & & & & & & & & & $\mathrm{X}$ & & & & & & \\
\hline & SPA-74 & & & & & & & & & & $\mathrm{x}$ & & & & & & & & & & & & & & & & & & & \\
\hline & SPB-07 & & & $\mathrm{X}$ & & & & & & & & & & & & & & & & & & & & $\mathrm{X}$ & & & & & & \\
\hline & SPB-10 & & & & & & & & & & & & & & & & & & & & & & & & & & & & & \\
\hline & SPB-12 & & & $\mathrm{X}$ & & & & & & & & & & & & & & & & & & & & & $\mathrm{X}$ & $\mathrm{X}$ & & & & \\
\hline & SPB-17 & & & $\mathrm{X}$ & & & & & & & & & & & & & & & & & $\mathrm{X}$ & $\mathrm{X}$ & & & & & & & & \\
\hline & SPB-45 & & & & & & & & & & & & & & & & & & & & & & & $\mathrm{X}$ & & & & & & \\
\hline & SPB-50 & & & & & & & & & & & & & & & & & & $\mathrm{X}$ & & & $\mathrm{x}$ & $\mathrm{X}$ & $\mathrm{X}$ & & & & $\mathrm{X}$ & & \\
\hline & SPB-65 & & & $\mathrm{X}$ & & & & & & & $\mathrm{X}$ & & & & & & & & & & & & & & & & & & & \\
\hline & SPC-30 & & & & & & & & & & & & & & & & & & & & & & & & & & & & & \\
\hline & SPC-36 & & & & & & & & & & $\mathrm{x}$ & & & & & & & & & & & & & & & & & & & \\
\hline & SPD-03 & & & & & & & & & & & & & & & & & & & & & & & $\mathrm{X}$ & & & & & & \\
\hline & SPD-10 & & & & & & & & & & $\mathrm{x}$ & & & & & & & & & & & & & & & & & & & \\
\hline & SPD-11 & & & & & & & & & & & & & & & & & & & & & & & $\mathrm{X}$ & & & & & & \\
\hline & SPD-27 & & & & & & & & & & & & & & & & & & & & & & & & & & & & & \\
\hline
\end{tabular}

Pachycondyla striata and Simopelta sp. (Ponerinae) and Linepithema sp. (Dolichoderinae).

Significant differences were observed between ant assemblages detected in the epigean and hypogean habitats (ANOSIM R $=0.487, \mathrm{p}=0.001$, Fig. 4). The total beta diversity ( $\beta_{\text {TотAL }}$ ) found between the epigean and hypogean environments corresponded to 0.65 . This compositional heterogeneity is explained by a nestedness pattern $\left(\beta_{\text {NESTEDNESS }}=0.36 ; \beta_{\text {TURNOVER }}=0.28\right)$.

\section{Ant richness and trophic guilds across cavities}

The dominant guild in the epigean environment listed in rank order include generalist ants (Dolichoderinae, Formicinae, Myrmicinae, Pseudomyrmecinae and Ectatomminae) (46.30\%); arboreal (16.67\%); litter- nesting fungus-growers (11.11\%) and large-sized epigean generalist predators (9.26\%). Dominant guilds in the hypogean environment were also the generalist ants (40\%); large-sized epigean generalist predators, litter-nesting fungus-growers and arboreal, (each at $13.33 \%)$. Regarding to the different types of cavities, the dominant guild was also generalist, but with different proportions: 50\% (mines), 42.86\% (caves) and $34.78 \%$ (impacted caves) (Fig. 5).

The number of guilds observed in the epigean habitats was slightly higher when compared to the cavities (Fig. 5). Furthermore, the epigean habitat contained some exclusive guilds, which were not observed in the cavities, the guilds were the mediumsized epigean generalist predators and the medium- 


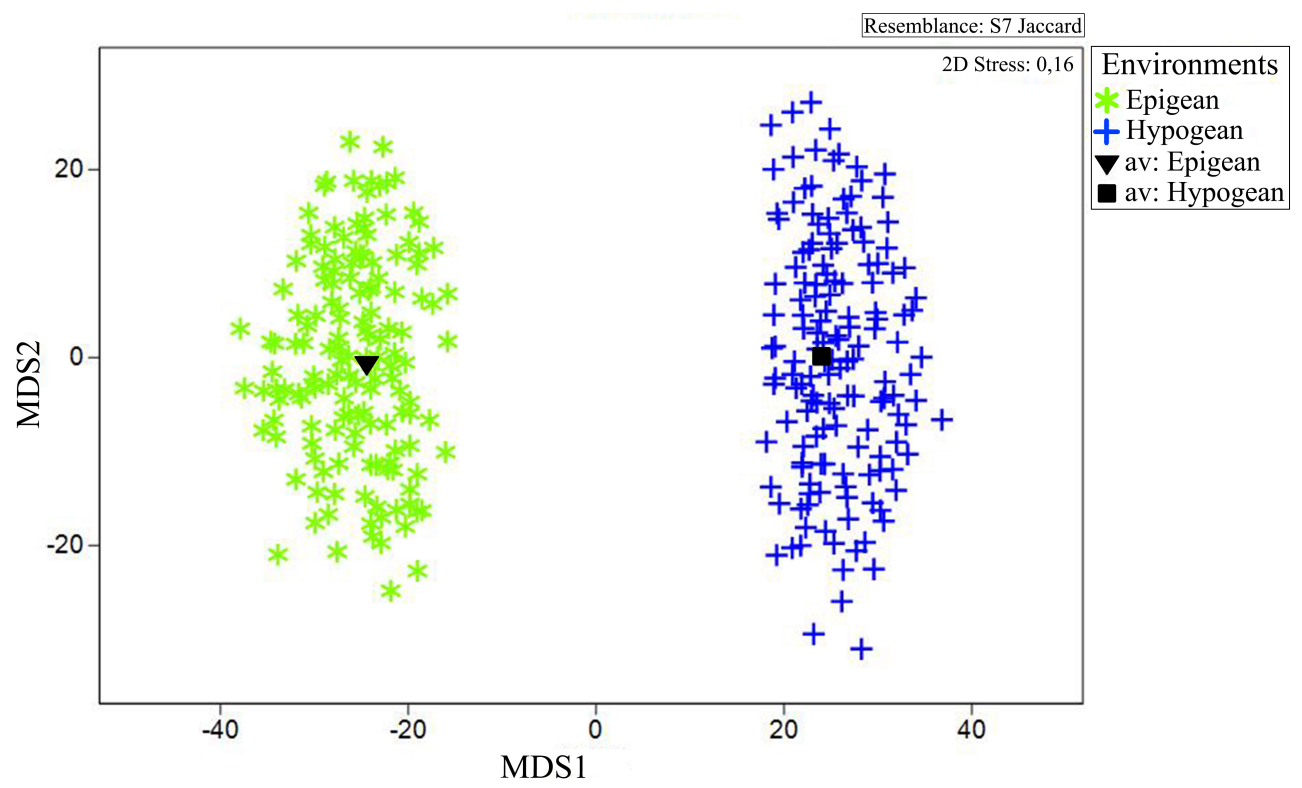

Fig. 4. Metric multidimensional scaling (MDS) and Bootstrap regions: 95\% (100 bootstraps per group) of ant species richness between epigean and hypogean habitats

sized hypogaeic generalist predators (only observed in the surroundings of cavities modified by man). The cavities with the highest diversity of guilds were the impacted caves (eight), caves (six) and mines (four). The hypogean environment contained only one exclusive guild: specialist predators living in the superficial soil layers; (Acropyga sp.), which was present only in the impacted caves category (Fig. 5).

The null hypothesis that the guild distribution is independent of the environment or of the cavity type was not rejected (chi-squared $=7.2645, p=0.61$; chisquared $=8.1774, \mathrm{p}=0.88$; respectively).

Influence of the cavity abiotic variables on the myrmecofauna

The richness of ants inside the cavities did not show a significant relationship with environment variables

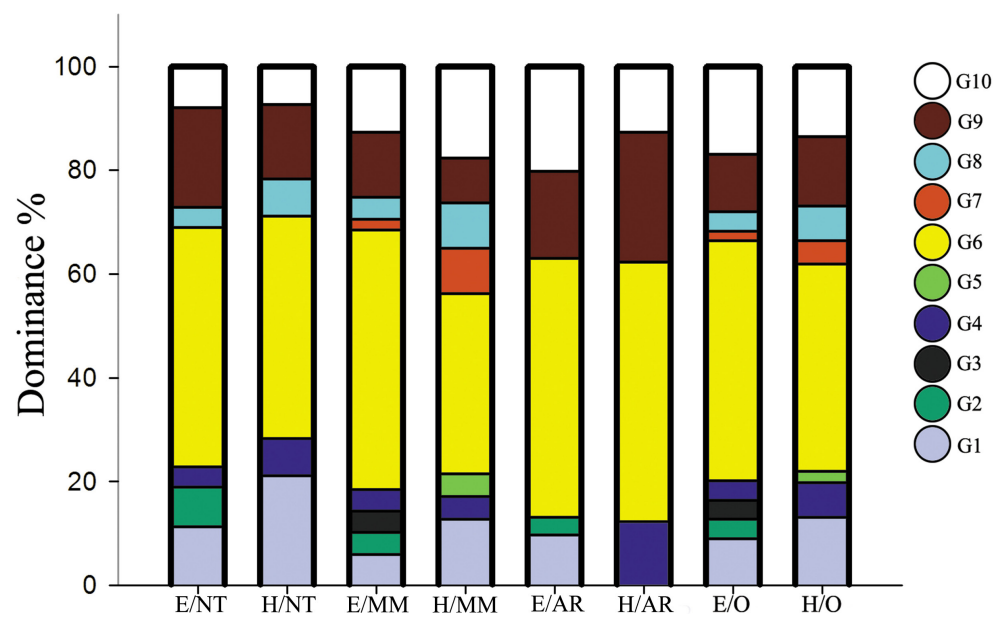

Fig. 5. Percentage and diversity of guilds in the epigean and hypogean environments for the different types of cavities. Legend: E/CA (epigean environment of caves), H/CA (hypogean environment of caves), E/IC (epigean environment of impacted caves), $\mathrm{H} / \mathrm{IC}$ (hypogean environment of impacted caves), E/MI (epigean environment of mines), $\mathrm{H} / \mathrm{Ml}$ (hypogean environment of mines), E/O (overall epigean), H/O (overall hypogean). The different colors represents the guilds are: $\mathrm{G} 1$ (Large-sized epigaeic generalist predators), G2 (Medium-sized epigaeic generalist predators), G3 (Medium-sized hypogaeic generalist predators), G4 (Hypogaeic generalist predators with vestigial eyes), G5 (Specialist predators living in the soil superficial layers), G6 (Generalists: generalized Dolichoderines, Formicines, and Myrmicines), G7 (Dacetini predators), G8 (Small-sized hypogaeic generalist foragers), G9 (Litter-nesting fungus-growers) and G10 (Arboreal ants) (type of cavity, altitude, distance between cavities, cavity length, slope, area, volume, number and size of entrances and environmental stability) ( $p \leq 0.05)$.

\section{DISCUSSION}

Studies related to the myrmecofauna from Brazilian caves (Ferreira, 2000; Dáttilo et al., 2010; Dáttilo et al., 2012) and in the world (Wilson, 1962; Tinaut \& Lopez, 2001; Roncin \& Deharveng, 2003; Moulds, 2006; Batucan \& Nuñeza, 2013; Figueras \& Nuñeza, 2013; Wynne \& Voyles, 2013; Dejean et al., 2015; Pape, 2016; Naka \& Maruyama, 2018) are limited regarding ant ecological function in the subterranean environment (Table 4). Ants usually are not target species for ecological studies in caves, as are other invertebrate groups - e.g., amphipods, cave salamander, copepods, beetles, isopods and spiders, as highlighted in a recent study surveyed by Mammola (2019). Furthermore, most of the studies in Brazil only report the occurrence of ants in caves (in general inventory studies), and ants were usually not identified beyond the family level (Table 4). Thus, this is one of the first studies examining cave use by ants especially in a poorly understood system, as are the iron ore cave systems.

\section{Cavity ant richness, composition and distribution patterns}

In Brazil there are three studies focusing on cave ant ecology (Ferreira, 2000; Dáttilo et al., 2010; Dáttilo et al., 2012). The study of Dáttilo et al. (2012) recorded 24 species in 27 natural cavities, a richness similar to that observed in the present study (26 species in 20 cavities). Furthermore, five of the 11 genera observed by Dáttilo et al. (2012) (Cephalotes, Crematogaster, Odontomachus, Pheidole and Solenopsis) were also found in cavities in this study. However, from those genera, only one presented an occurrence of a single morphospecies in more than five 
Table 4. Ant assemblages recorded in Brazilian cavities between 1987-2019 by other authors.

\begin{tabular}{|c|c|c|c|c|c|c|c|c|c|c|c|c|c|c|c|c|c|c|c|c|c|}
\hline Subfamily/Genus & 1 & 2 & 3 & 4 & 5 & 6 & 7 & 8 & 9 & 10 & 11 & 12 & 13 & 14 & 15 & 16 & 17 & 18 & 19 & 20 & 21 \\
\hline Amblyoponinae & & & & & & & & & & & & & & & & & & + & & & \\
\hline \multicolumn{22}{|l|}{ Cerapachyinae } \\
\hline \multicolumn{22}{|l|}{ Acanthostichus kirbyi Emery, 1895} \\
\hline Myrmicinae & + & & & & & + & & + & & & & + & + & + & + & & & & & & \\
\hline Acromyrmex spp. & & & & & & + & & + & & & & & & + & & & & & & & \\
\hline Atta sexdens (LINNAEUS, 1758) & & & & & & & & & & & & & & & + & & & & & & \\
\hline Atta spp. & + & & & & & & & + & & & & & + & & & & & & + & & \\
\hline Cephalotes bruchi (FOREL, 1912) & & & & & & & & & & & & & & & + & & & & & & \\
\hline Cephalotes sp. & & & & & & & & & & & & & & & & & & & + & & \\
\hline Crematogaster sp. & & & & & & & & & & & & & & & & & & & + & & \\
\hline Pheidole spp. & & & & & & + & & + & & & & & & & + & & & & & & + \\
\hline Solenopsis spp. & & & & & & + & & + & & & & + & & + & + & & & + & + & + & + \\
\hline Strumigenys spp. & & & & & & + & & + & & & & & & & & & & & & & \\
\hline $\begin{array}{l}\text { Wasmannia auropunctata } \\
\text { (Roger, 1863) }\end{array}$ & & & & & & & & & & & & & & & & & & & & & + \\
\hline Formicinae & & + & & + & & + & & + & & & & + & & + & & + & + & & & & \\
\hline Brachymyrmex spp. & & & & & & & & & & & & + & & + & & & & + & & & \\
\hline $\begin{array}{l}\text { Camponotus femoratus } \\
\text { (FABRICIUS, 1804) }\end{array}$ & & + & & & & & & + & & & & & & & & & & & & & \\
\hline Camponotus spp. & & & & + & & + & & + & & & & & & + & & & & & + & & \\
\hline Nylanderia sp. & & & & & & & & & & & & & & & & & & + & & & + \\
\hline Paratrechina spp. & & & & & & + & & + & & & & & & & & & & & & & \\
\hline Dolichoderinae & & & & & & + & & + & & & & & & + & & & & & & & \\
\hline Azteca sp. & & & & & & & & & & & & & & + & & & & & & + & \\
\hline Forelius spp. & & & & & & + & & + & & & & & & & & & & & & & \\
\hline Iridomyrmex spp. & & & & & & & & + & & & & & & & & & & & & & \\
\hline Linepithema spp. & & & & & & & & & & & & & & & & & & & + & & \\
\hline Pseudomyrmecinae & & & & & & + & & + & & & & & & & & & & & & & \\
\hline Pseudomyrmex spp. & & & & & & + & & + & & & & & & & & & & & & & \\
\hline Ecitoninae & & & + & & & + & & + & & & & & & & & & & & & & \\
\hline Labidus coecus spp. & & & + & & & + & & + & & & & & & & & & & & & & + \\
\hline Labidus spp. & & & & & & + & & + & & & & & & & & & & & & & \\
\hline Neivamyrmex spp. & & & & & & + & & + & & & & & & & & & & & & & \\
\hline Ponerinae & & & & + & + & + & + & + & + & + & + & + & & + & & & & & & & \\
\hline Gnamptogenys spp. & & & & & & + & & + & & & & & & + & & & & & & & \\
\hline Hypoponera spp. & & & & & + & + & & + & & & & + & & & & & & & + & & + \\
\hline Leptogenys sp. & & & & & & & & & & & & & & & & & & & & & + \\
\hline Odontomachus spp. & & & & & & & & & + & & + & & & + & & & & + & + & + & \\
\hline Pachycondyla spp. & & & & + & + & + & & + & & & & & & + & & & & & & & \\
\hline
\end{tabular}

Legend: (1) Trajano (1987); (2) Moreira and Paiva (1988); (3) Trajano and Gnaspini-Netto (1991); (4) Trajano and Moreira (1991); (5) Trajano (1992); (6) Gnaspini and Trajano (1994); (7) Gnaspini et al. (1994); (8) Pinto-da-Rocha (1995); (9) Souza-Silva and Ferreira (2009); (10) Trajano and Bichuette (2009); (11) Ferreira et al. (2010); (12) Bernardi et al. (2011); (13) Souza-Silva et al. (2011); (14) Soares at al. (2013); (15) Gallão and Bichuette (2015); (16) Souza-Silva and Ferreira (2015); (17) Simões et al. (2015); (18) Ferreira et al. (2016), (18) Zepon and Bichuette (2017), (19) Bichuette et al. (2017), (20) Sousa et al. (2017), (21) Bichuette et al. (2019).

cavities (Solenopsis), the others were restricted to four or fewer cavities. The higher frequency of those two genera may be explained not only by their wide distribution throughout the continent (Brandão, 1999), but also by the possible affinity of these genera for foraging in underground environments. Solenopsis genera is usually more easily found in the hypogaeic assemblage than on the surface (Fowler et al., 2000). The others may be opportunistic or even accidental species. The high connectivity of iron ore cavities with the surrounding epigean environment (Ferreira, 2005), favors organic matter accumulation near cavity entrances, providing potential places for foraging and favoring the access to the subterranean habitats (Pape, 2016), enlarging cave ant richness by those opportunistic species.

On the other hand, the ant species found in cavities were restricted to a very few occurrences, being more widespread within the surface environment. This finding indicates a low affinity of those restricted species for the subterranean environment. In deeper portions of the cavities, the scarcity of food resources may restrict the occurrence of many species (Culver \& Pipan, 2019), including ants.

The presence of pre-adaptations to subterranean environments such as mechanisms for orientation in 
aphotic habitats and presence of metapleural glands, especially present in edaphic species, precludes characterizing most ant species as accidental. However, these characteristics do not necessarily lead to the use or colonization of the subterranean environment. It is important to highlight that ants may effectively take part in the cavity community in several ways, either through their trophic contribution, by depositing ant midden materials (Ferreira, 2000) or being competitors and predators e.g., Solenopsis invicta (Pape, 2016) and decomposing processes (Cokendolpher et al., 2009; Pape, 2016). They can also be considered as invasive species (Ferreira, 2019). Despite the many observations of ant species in Brazilian caves and in the world, only two are considered as truly troglobiotic species. The first is a Ponerine ant, Leptogenys khammouanensis Rocin \& Deharveng, 2003 from Laos (Rocin \& Deharveng, 2003). The second species was recently discovered and described, is a Myrmicinae ant, Aphaenogaster gamagumayaa Naka \& Maruyama, 2018 found in Japan (Naka \& Maruyama, 2018).

\section{Epigean and hypogean richness, composition and diversity patterns of ants}

The comparisons of epigean and hypogean ants in this study showed that even with the high connectivity between environments (Ferreira 2005), lower ant species richness was found in the subterranean habitats. This scarcity of ant species that colonize the subterranean environment also reflects the number of troglobiotic ant species, as mentioned earlier. According to Wilson (1962), the organization of ants in colonies requires a minimum population sizes. Large ant populations allow sufficient genetic variability between the different reproductive castes, which would enable speciation in caves (Wilson, 1962). The oligotrophy stresses in caves hinder the existence of large ant colonies. Alternatively, smaller colonies sizes and increased polygamy and polygyny, are more likely to occur in the subterranean environment (Tinaut $\&$ Lopez, 2001). However, these changes can lead to the deconstruction of ant social life (Tinaut \& Lopez, 2001).

These environmental conditions of the subterranean habitat and ant behavioral characteristics are probably the main drivers of the beta diversity pattern found in this study. We suggest the nesting component is the primary factor responsible for the differences observed among environments. Furthermore, ant nests were not found inside the sampled cavities, suggesting that the individuals detected within cavities likely represented individuals from surface populations. Thus, it seems that the ants enter the cavity only for foraging.

\section{Richness and trophic guilds among cavities}

Caves can be considered extreme or harsh environments for most surface and soil organisms (Howarth, 1983) and these environments are more likely to support animals that can deal with a large variety of conditions and resource supplies. Ants often exhibit a high specificity for habitat type, as exemplified by hypogaeic, leaf litter and arboreal ants (Silva \& Silvestre, 2004; Nascimento, 2011; Figueiredo et al., 2013). Hence, it is expected that some guilds would not be able to tolerate the cavity harshness. In this perspective, the dominance of guilds composed of generalist ants (Dolichoderinae, Formicinae and Myrmicinae) was expected since oligotrophy usually favors species with less restrictive diets. On the other hand, specialist species tend to be less common in cave environments. However, the predominance of generalist guilds was observed both in the epigean and hypogean environments. This pattern may be explained by the fact that it is the most common trophic guild, covering less restrictive diets within ants (Delabie et al., 2000; Silva \& Brandão, 2010). Litter-nesting fungus-growing ants present in the cavities obtain their resources from decomposing organic matter and guano present in such habitats (Dáttilo et al., 2012; Dejean et al., 2015).

Impacted caves in this study contained more microhabitats when compared to artificial and natural galleries. We infer that human actions transformed such cavities into a more diversified environment, since excavations created larger, branched conduits, and made more microhabitats available due to the presence of collapsed rocks associated with the cavity, potentially providing more niches for ants. A pattern well recognized by the scientific community is that diversity in one level of the ecosystem tends to beget diversity in other levels (Armbrecht et al., 2004). This may explain the pattern found in this type of cavity.

Although the different types of cavities have a distinct habitat structure, the microclimate and trophic conditions remain similar, which allows the high similarity among the ant assemblages. Studies comparing the invertebrate fauna in natural cavities and artificial galleries speculate that the faunal similarity results from similar physical and tropic conditions (Peck, 1988; Ferreira, 2004; Bernardi, 2011). Moreover, the predominance of generalist species reduces the differences of composition among cavities, since generalist species can colonize a large range of environments. However, in the present study, a lower diversity of guilds was observed for mines. Furthermore, the guilds in artificial galleries contained a higher percentage of generalist species, thus allowing the inference that these environments do not follow the same pattern for ants, even with physical conditions common to other types of cavities. This situation was probably caused by the lower environmental heterogeneity of the artificial galleries when compared to the natural cavities and those modified by man, which are characterized by linear and homogeneous conduits.

Although it was expected that guilds containing large-sized epigean generalist predators and mediumsized epigean generalist predators would occur only in the epigean environment, due to the oligotrophy condition found in cavities, predators were found in both preserved and impacted caves. Their occurrence is probably explained by less competition with other predators, since cavities can act as biological filters preventing the colonization of many species (Culver \& Pipan, 2019), mainly in the those preserved, in which generalist predator ants occurred more frequently. 
Lastly, it was observed that arboreal ants occur in a broader spectrum than could be previously expected. We speculate that this guild can be foraging in other environments including iron-ore cavities.

The result of a chi-square test reinforces that there is no subterranean filter for trophic guilds across the three cavity types. In this sense, the distribution of myrmecofauna in the study region occurs independently of the environment and type of cavity with which they were detected.

\section{Influence of the subterranean abiotic variables on the myrmecofauna}

The environmental variables analyzed did not appear to influence the richness of ant assemblages. Although the species-area relationship is remarkable in ecology (MacArthur \& Wilson, 1967), this relation was not observed for the myrmecofauna in the present study. Richer subterranean invertebrate communities are usually associated with larger habitats (regarding cavity size) (Ferreira, 2004; Simões et al., 2015; Ferreira \& Pellegrini, 2019) and this relationship tends to be more pronounced in iron ore caves, when compared to cavities in other lithologies (Souza-Silva et al., 2011). However, this study, as well as that of Dattilo et al. (2012) did not find this relationship. Ants were not related to other environmental variables, and this may be due to a weaker association with cavities when compared to troglophilic invertebrates. Thus, it is possible to infer that most of the ants can enter sporadically (or even constantly) in subterranean systems, being "transient" in these systems, without, in fact, establishing colonies. Accordingly, since they do not live preferentially in these habitats, the structure of their assemblages is only weakly determined (or influenced) by the physical variables of these habitats.

\section{Final considerations}

Even though cavities are restrictive to colonization by many kinds of organisms, iron ore cavities supported a significant portion of the local epigean ant diversity. Constraints to the ant fauna use of the cavities in this study did not present a significant relationship with cavities physical characteristics. Most of the ant assemblages observed are generalist groups. Therefore, such organisms may take part indirectly (as opportunists) and/or directly in the community and subterranean environment by interspecific interactions. Ants can also transport nutrients into caves - e.g., by ant middens (Ferreira, 2000), and eventually remove nutrients from the cavities - e.g., by collecting food resources from bat guano deposits (Ferreira, 2019).

\section{ACKNOWLEDGMENTS}

We thank Chaim Lasmar and the team from the Laboratory of Ant Ecology (UFLA) for confirming our identifications; Pierre Munaro, Thadeu Pietrobon, Maysa Villela R. Souza and Daniela C. Pompeu for helping in the fieldwork; Luiz Iniesta and Lucas Rabelo for helping with the study area maps; Ataliba Henrique
Fraga Coelho for cave topography information; Paulo Pompeu for the help with statistical analyses. We thank Vale S.A., Coordenação de Aperfeiçoamento de Pessoal de Nivel Superior (CAPES), National Council of Technological and Scientific Development (CNPq) and Fundação de Amparo à Pesquisa do Estado de Minas Gerais (FAPEMIG) for the research financial support. RLF is grateful to the National Council of Technological and Scientific Development (CNPq research grant No. 308334/2018-3). We are also grateful to Jut Wynne and the anonymous reviewer for their suggestions and valuable comments that significantly improved the text.

\section{REFERENCES}

Alvares C.A., Stape J.L., Sentelhas P.C., Moraes G., Leonardo J. \& Sparovek G., 2013 - Köppen's climate classification map for Brazil. Meteorologische Zeitschrift, 22 (6): 711-728.

https://doi.org/10.1127/0941-2948/2013/0507

Armbrecht I., Perfecto I. \& Vandermeer J., 2004 Enigmatic biodiversity correlations: ant diversity responds to diverse resources. Science, 304: 284-286. https://doi.org/10.1126/science.1094981

Auler A.S., Piló L.B., Parker C.W., Senko J.M., Sasowsky I.D. \& Barton H.A., 2014 - Hypogene cave patterns in iron ore caves: convergence of forms or processes? In: Klimchouk A., Sasowsky I., Mylroie J., Engel S. \& Engel A.S. (Eds.), Hypogene cave morphologies: Selected papers and abstracts of the symposium held. February 2-7, San Salvador Island, Bahamas, 111 p.

Ayres M., Ayres J.R.M., Ayres D.L. \& Santos A.S., 2007 - BioEstat 5.0-Aplicações Estatísticas nas Áreas das Ciências Biológicas e Médicas: Sociedade Civil Mamirauá, Belém. CNPq, Brasília, 290 p.

Baccaro F.B., 2006 - Chave para as principais subfamílias e gêneros de formigas (Hymenoptera: Formicidae). INPA, Programa de pesquisa em Biodiversidade-PPBIO, Faculdades Cathedral, Manaus, 34 p.

Baccaro F.B., Feitosa R.M., Fernandez F., Fernandes I.O., Izzo T.J., Souza J.L.P. \& Solar R., 2015 - Guia para os gêneros de formigas do Brasil. Manaus, Editora INPA, $388 \mathrm{p}$.

Baselga A. \& Orme C.D.L., 2012 - Betapart: an R package for the study of beta diversity. Methods in Ecology and Evolution, 3: 808-812. https://doi.org/10.1111/j.2041-210X.2012.00224.x

Batucan J.R.L.S. \& Nuñeza O.M., 2013 - Ant species richness in caves of Siargao Island protected landscape and seascape, Philippines. ELBA Bioflux, 5: 83-92.

Beattie A.J., 2010 - Antimicrobial defenses in ants: pure and applied science. In: Lach L., Parr C.L. \& Abbott K.L. (Eds.), Ant ecology. Oxford University Press, New York, 429 p.

Bento D.D.M., Ferreira R.L., Prous X., Souza-Silva M., Bellini B.C. \& Vasconcellos A., 2016 - Seasonal variations in cave invertebrate communities in the semiarid Caatinga, Brazil. Journal of Caves and Karst Studies, 78: 61-71.

https://doi.org/10.4311/2015LSC0111

Bernardi L.F.O., Souza-Silva M. \& Ferreira R.L., 2011 Efeitos do uso turístico sobre cavidades subterrâneas artificiais: subsidios para o uso antrópico de sistemas subterrâneos. Tourism and Karst Areas, 2: 71-88.

Bichuette M.E., Nascimento A.R., Von Schimonsky D.M., Gallão J.E., Resende L.P. \& Zepon T., 2017 - Terrestrial fauna of the largest granitic cave from Southern 
Hemisphere, southeastern Brazil: A neglected habitat. Neotropical Biology and Conservation, 12 (2): 75-90. https://doi.org/10.4013/nbc.2017.122.01

Bichuette M.E., Simões L.B., Zepon T., Von Schimonsky D.M. \& Gallão J.E., 2019 - Richness and taxonomic distinctness of cave invertebrates from the northeastern state of Goiás, central Brazil: a vulnerable and singular area. Subterranean Biology, 29: 1-33.

https://doi.org/10.3897/subtbiol.29.30418

Brandão C.R.F., 1999 - Reino Animalia: Formicidae. In: Joly C.A. \& Cancello E.M. (Eds.), Invertebrados terrestres. Biodiversidade do Estado de São Paulo: sintese do conhecimento ao final do século XX. São Paulo, FAPESP, 279 p.

Carmo F.F., 2010 - Importância ambiental e estado de conservação dos ecossistemas de cangas no Quadrilátero Ferrífero e Proposta de áreas-alvo para a investigação e proteção da biodiversidade em Minas Gerais. MSc Dissertation, Universidade Federal de Minas Gerais, 90 p.

Cecav, 2017 - Legislação espeleológica. http://www. icmbio.gov.br/cecav/downloads/legislacao.html [accessed 21 February 2017].

Clarke K.R. \& Gorley R.N., 2015 - Primer V7: User manual/tutorial. Plymouth: Primer-E.

Cokendolpher J.C., Reddell J.R., Taylor S.J., Krejca J.K., Suarez A.V. \& Pekins C.E., 2009 - Further ants (Hymenoptera: Formicidae) from caves of Texas. In: Cokendolpher J.C. \& Reddell J.R. (Eds.), Studies on the cave and endogean fauna of North America, $V$. Texas Memorial Museum Speleological Monographs, p. 151-168.

Culver D.C., 1982 - Cave Life. Evolution and Ecology. Harvard University Press, Cambridge, 189 p. https://doi.org/10.4159/harvard.9780674330214

Culver D.C. \& Pipan T., 2019 - The Biology of Caves and Other Subterranean Habitats. Oxford University Press, UK, $273 \mathrm{p}$.

https://doi.org/10.1093/oso/9780198820765.001.0001

Dáttilo W., Vicente R.E., Nunes R.V. \& Gligliotti M.S., 2010 - Primeiro registro da quenquém cisco-daAmazônia Acromyrmex hystrix (Latreille) (Formicidae: Myrmicinae) para o estado do Maranhão, Brasil. EntomoBrasilis, 3: 92-93.

https://doi.org/10.12741/ebrasilis.v3i3.109

Dáttilo W., Vicente R.E., Nunes R.V. \& Feitosa R.M., 2012 - Influence of Cave Size and Presence of Bat Guano on Ant Visitation. Sociobiology, 59: 549-559.

https://doi.org/10.13102/sociobiology.v59i2.617

Dejean A., Groc S., Hérault B., Rodriguez-Pérez H., Touchard A., Cereghino R., Delabie J.H.C. \& Corbara B., 2015 - Bat aggregation mediates the functional structure of ant assemblages. Comptes rendus biologies, 338: 688-695.

https://doi.org/10.1016/j.crvi.2015.06.011

Delabie J.H.C., Agosti D. \& Nascimento I.C., 2000 Litter ant communities of the Brazilian Atlantic rain forest region. In: Agosti D., Majer J.D., Alonso L.E. \& Schultz T. (Eds.), Sampling ground-dwelling ants: case studies from the world's rain forests. Bulletin number 18. Curtin University School of Environmental Biology, Perth, Australia, p. 1-10.

Dorr J.V.N., 1973 - Iron-Formation in South America. Economic Geology, 68: 1005-1022.

https://doi.org/10.2113/gsecongeo.68.7.1005

Farias A.A. \& Jaksic F.M., 2006 - Assessing the relative contribution of functional divergence and guild aggregation to overall functional structure of species assemblages. Ecological Informatics, 1: 367-375.

https://doi.org/10.1016/j.ecoinf.2006.09.003
Ferreira R.L., 2000 - "Lixeiras de formigueiro": recursos adicionais em sistemas cavernícolas? Estudo de caso: Toca do Morrinho (Campo Formoso, Bahia). O Carste, 12: $154-158$.

Ferreira R.L., 2004 - A medida da complexidade ecológica e suas aplicações na conservação e manejo de ecossistemas subterrâneos. $\mathrm{PhD}$ Dissertation. Universidade Federal de Minas Gerais, $158 \mathrm{p}$.

Ferreira R.L., 2005 - A vida subterrânea nos campos ferruginosos. O Carste, 3: 106-115.

Ferreira R.L., Prous X., Bernardi L.F.O. \& Souza-Silva M., 2010 - Fauna subterrânea do Estado do Rio Grande do Norte: caracterização e impactos. Revista Brasileira de Espeleologia, 1: 1-27.

Ferreira R.L., de Oliveira M.P.A. \& Souza-Silva M., 2015 - Biodiversidade subterrânea em geossistemas ferruginosos. In: Carmo F.F. \& Kamino L.H.Y. (Eds.). Geossitemas Ferruginos do Brasil: áreas prioritárias para conservação da diversidade geológica e biológica, patrimônio cultural e serviços ambientais. Belo Horizonte, 3i Editora, p. 195-231.

Ferreira R.L., Cardoso R.C. \& Souza-Silva M., 2016 Composição, riqueza e diversidade de invertebrados em cavernas de Dianópolis (TO). Revista Brasileira de Espeleologia, 2: 1-18.

Ferreira R.L., de Oliveira M.P.A. \& Souza-Silva M., 2018 - Subterranean biodiversity in ferruginous landscapes. In: Moldovan O.T., Kováč L. \& Halse S. (Eds.), Cave Ecology. Springer, Cham, p. 435-447. https://doi.org/10.1007/978-3-319-98852-8_21

Ferreira R.L. \& Pellegrini T.G., 2019 - Species-area model predicting diversity loss in an artificially flooded cave in Brazil. International Journal of Speleology, 48 (2): 155165. https://doi.org/10.5038/1827-806X.48.2.2244

Ferreira R.L., 2019 - Guano communities. In: White W.B., Culver D.C. \& Pipan T. (Eds.), Encyclopedia of Caves. Academic Press, Elsevier, p. 474-484.

https://doi.org/10.1016/B978-0-12-814124-3.00057-1

Figueiredo C.J., Silva R.R., Munhae C.B. \& Morini M.S.C., 2013 - Ant fauna (Hymenoptera: Formicidae) attracted to underground traps in Atlantic Forest. Biota Neotropica, 13 (1): 176-182.

https://doi.org/10.1590/S1676-06032013000100020

Figueras G.S. \& Nuňeza O.M., 2013 - Species diversity of ants in karst limestone habitats in Bukidnon and Davao Oriental, Mindanao, Philippines. AES Bioflux, 5: 306-315.

Formigas do brasil.com, 2014-2015 - Formigas Brasil. com Um Blog sobre Mirmecologia. http://www. formigasbrasil.com/ [accessed 13 May 2015].

Fowler H.G., Delabie J.H.C. \& Moutinho P.R.S., 2000 Hypogaeic and epigaeic ant (Hymenoptera: Formicidae) assemblages of Atlantic costal rainforest and dry mature and secondary Amazon forest in Brazil: Continuums or communities. Tropical Ecology, 41 (1): 73-80.

Gallão J.E. \& Bichuette M.E., 2015 - Taxonomic distinctness and conservation of a new high biodiversity subterranean area in Brazil. Anais da Academia Brasileira de Ciências, 87: 209-217. https://doi.org/10.1590/0001-3765201520140312

Gnaspini P. \& Trajano E., 1994 - Brazilian cave invertebrates, with a checklist of troglomorphic taxa. Revista Brasileira de Entomologia, 38 (3/4): 549-584.

Gnaspini P., Trajano E. \& Sánchez L.E., 1994 - Província espeleológica da Serra da Bodoquena, MS: exploração, topografia e biologia. Espeleo-Tema, 17: 19-44.

Howarth F.G., 1980 - The zoogeography of specialized cave animals: A bioclimatic model. Evolution, 34: 394-406. https://doi.org/10.1111/j.1558-5646.1980.tb04827.x 
Howarth F.G., 1983 - Ecology of cave arthropods. Annual review of entomology, 28 (1): 365-389.

https://doi.org/10.1146/annurev.en.28.010183.002053

Inmet, 2015 - Instituto Nacional de Meteorologia. www. inmet.gov.br [accessed 13 May 2015].

Jaffé R., Prous X., Calux A., Gastauer M., Nicacio G., Zampaulo R., Souza-Filho P.W.M., Oliveira G., Brandi I.V. \& Siqueira J.O., 2018 - Conserving relics from ancient underground worlds: assessing the influence of cave and landscape features on obligate iron cave dwellers from the Eastern Amazon. PeerJ, 6: e4531. https://doi.org/10.7717/peerj.4531

Mammola S., Cardoso P., Culver D.C., Deharveng L., Ferreira R.L., Fiser C., Galassi D.M.P., Grielber C., Halse S., Humphreys W.F., Isaia M., Malard F., Martinez A., Moldovan O.T., Niemiller M.L., Pavlek M., Reboleira A.S.P.S., Souza-Silva M., Teeling E.C., Wynne J.J. \& Zagnajster M., 2019 - Scientists' warning on the conservation of subterranean ecosystems. BioScience, 69 (8): 641-650.

https://doi.org/10.1093/biosci/biz064

Mammola S., 2019 - Finding answers in the dark: caves as models in ecology fifty years after Poulson and White. Ecography, 42 (7): 1331-1351.

https://doi.org/10.1111/ecog.03905

MacArthur R.H. \& Wilson E.O., 1967 - The theory of Island Biogeography. Princeton University Press, Princeton, $224 \mathrm{p}$.

McCune B. \& Grace J.B., 2002 - Analysis of ecological communities. Gleneden Beach, Oregon, USA, 300 p.

Moulds T., 2006 - The first Australian record of subterranean guano-collecting ants. Helictite, 39: 3-4.

Moreira J.R.A. \& Paiva R.S., 1988 - Levantamento bioespeleológico preliminary da Serra dos Carajás - PA - Brasil. Congresso de Espeleologia da América Latina e do Caribe, 1o Anais, Belo Horizonte, Sociedade Brasileira de Espeleologia, p. 142-150.

Morueta-Holme N., Oldfather M.F., Olliff-Yan R.L., Weitz A.P., Levine C.R., Kling M.M., Riordan E.C., Merow C., Sheth S.N., Thornhill A.H. \& Ackerly D.D., 2018 - Best practices for reporting climate data in ecology. Nature Climate Change, 8: 92-94.

https://doi.org/10.1038/s41558-017-0060-2

Nascimento R.P., 2011 - Estrutura de comunidades de formigas no cerrado:diversidade, composição e atividade predátoria em monocultura em ecossitemas naturais. PhD Thesis. Universidade Federal de Urberlândia, 160 p.

Naka T. \& Maruyama M., 2018 - Aphaenogaster gamagumayaa sp. nov.: the first troglobiotic ant from Japan (Hymenoptera: Formicidae: Myrmicinae). Zootaxa, 4450 (1): 135-141.

https://doi.org/10.11646/zootaxa.4450.1.10

Pape R.B., 2016 - The importance of ants in cave ecology, with new records and behavioral observations of ants in Arizona caves. International Journal of Speleology, 45 (3): 185-205.

https://doi.org/10.5038/1827-806X.45.3.1936

Peck S.B., 1988 - A review of the cave fauna of Canada, and the composition and ecology of the invertebrate fauna of caves and mines in Ontario. Canadian Journal of Zoology, 66: 1197-1213.

https://doi.org/10.1139/z88-176

Pellegrini T.G., Sales L.P., Aguiar P. \& Ferreira R.L., 2016 - Linking spatial scale dependence of landuse descriptors and invertebrate cave community composition. Subterranean Biology, 18: 17-38. https://doi.org/10.3897/subtbiol.18.8335

Pierre M., 2011 - Speleology comparative study underground cavities, impacted and man-made in iron formations. Anais do $31^{\circ}$ Congresso Brasileiro de
Espeleologia. Ponta Grossa - PR, 21-24 de Julho de 2011 - Sociedade Brasileira de Espeleologia, p. 506-514.

Piló L.B., Coelho A. \& Reino J.C.R., 2015 - Geospeleologia em rochas ferríferas: cenário atual e conservação. In: Carmo F.F. \& Kamino L.H.Y. (Eds.), Geossitemas Ferruginos do Brasil: áreas prioritárias para conservação da diversidade geológica e biológica, patrimônio cultural e serviços ambientais. Belo Horizonte, 3i Editora, p. 553.

Pinto-Da-Rocha R., 1995 - Sinopse da fauna cavernícola do Brasil (1907-1994). Papéis Avulsos de Zoologia, 36: 145-147.

Poulsen M., Hughes W.O.H. \& Boomsma J.J., 2006 Differential resistance and the importance of antibiotic production in Acromyrmex echinatior leaf-cutting and castes towards the entomopathogenic fungus Aspergillus nomius. Insectes Sociaux, 53 (3): 349-355. https://doi.org/10.1007/s00040-006-0880-y

Pomerene J.B., 1964 - Geology and ore deposits of the Belo Horizonte, Ibirité, and Macacos quadrangles, Minas Gerais, Brazil. Geological Survey Professional Paper, 341: 1-84. https://doi.org/10.3133/pp341D

$\mathrm{R}$ Development Core Team, 2016 - R: A language and rnvironment for statistical computing. $\mathrm{R}$ Foundation for Statistical Computing, Vienna, Austria. https://www.R-project.org/

Roncin E. \& Deharveng L., 2003 - Leptogenys khammouanensis $s p$. nov. (Hymenoptera: Formicidae). A possible troglobitic species of Laos, with a discussion on cave ants. Zoological Science, 20: 919-924. https://doi.org/10.2108/zsj.20.919

Santos L.M., 2013 - Mapeamento dos usos e coberturas do solo desenvolvidos sobre substratos ferriferos no Quadrilátero Ferrífero. Relatório Final. Vale, laboratório de Solos da Universidade federal de Viçosa, Isaviçosa e Bioma Meio Ambiente, 37 p.

Schaefer C.E., Cândido H.G., Corrêa G.R., Pereira A., Nunes J.A., Souza O.F., Marins A., Filho E.F. \& Ker J.C., 2015 - Solos desenvolvidos sobre canga ferruginosa no Brasil: uma revisão crítica e papel ecológico de termiteiros. In: Do Carmo F.F. \& Kamino L.H.Y. (Eds.) Geossistemas ferruginosos do Brasil: áreas prioritárias para conservação da diversidade geológica e biológica, patrimônio cultural e serviços ambientais. 3i Editora, Belo Horizonte, 552 p.

Schmidt F.A. \& Solar R.R.C., 2010 - Hypogaeic pitfall traps: methodological advances and remarks to improve the sampling of a hidden ant fauna. Insectes Sociaux, 57 (3): 261-266.

https://doi.org/10.1007/s00040-010-0078-1

Sharratt N.J., Picker M.D. \& Samways M.J., 2000 - The invertebrate fauna of the sandstone of the caves of the Cape Peninsula (South Africa): patterns of endemism and conservation priorities. Biodiversity and Conservation, 9: 107-143. https://doi.org/10.1023/A:1008968518058

Silva R.R. \& Silvestre R., 2004 - Riqueza da fauna de formigas (hymenoptera: formicidae) que habita as camadas superficiais do solo em Seara, Santa Catarina. Papéis Avulsos de Zoologia, 44: 1-11.

https://doi.org/10.1590/S0031-10492004000100001

Silva R.R. \& Brandão C.R.F., 2010 - Morphological patterns and community organization in leaf-litter ant assemblages. Ecological Monographs, 80: 107-124. https://doi.org/10.1890/08-1298.1

Simões M.H., Souza-Silva M. \& Ferreira R.L., 2015 - Cave physical attributes influencing the structure of terrestrial invertebrate communities in Neotropics. Subterranean Biology, 16: 103-121.

https://doi.org/10.3897/subtbiol.16.5470

Simmons G.C., 1960 - Origin of certain cangas of the "Quadrilátero Ferrifero" of Minas Gerais, Brazil. Boletim da Sociedade Brasileira de Geologia, 9: 37-59. 
Soares L.G.S., Van-de-Koken A.F., Timo M.B. \& da-Silva R.P., 2013 - Fauna de invertebrados em cavernas de calcário na região de Córrego Fundo, Minas Gerais, Brasil. Revista Eletrônica de Biologia (REB), 6 (1): 48-68.

Souza-Silva M. \& Ferreira R.L., 2009 - Caracterização ecológica de algumas cavernas do Parque Nacional de Ubajara (Ceará) com considerações sobre o turismo nestas cavidades. Revista de Biologia e Ciências da Terra, 9: 59-71.

Souza-Silva M., Martins R.P. \& Ferreira R.L., 2011 - Cave lithology determining the structure of the invertebrate communities in the Brazilian Atlantic Rain Forest. Biodiversity and Conservation, 20: 1713-1729. https://doi.org/10.1007/s10531-011-0057-5

Sousa P.R., Souza-Silva M., Ferreira R.L.L. \& Zampaulo R.A., 2017 - Is an outstanding environment always preserved? When the most diverse cave in subterranean species becomes one of the most endangered in a landscape. Revista Brasileira de Espeleologia, 2 (8): 1-23.

Souza-Silva M., Martins R.P. \& Ferreira R.L., 2015 - Cave conservation priority index to adopt a rapid protection strategy: a case study in Brazilian Atlantic rain forest. Environmental management, 55 (2): 279-295. https://doi.org/10.1007/s00267-014-0414-8

Souza-Silva M. \& Ferreira R.L., 2015 - Cave invertebrates in Espirito Santo state, Brazil: a primary analysis of endemism, threats and conservation priorities. Subterranean Biology, 16: 79-102. https://doi.org/10.3897/subtbiol.16.5227

Tinaut A. \& Lopez F., 2001 - Ants and caves: sociability and ecological constraints (Hymenoptera, Formicidae). Sociobiology, 37: 651-659.

Toy T.J., Griffith J.J. \& Ribeiro C.R.F., 2001 - Planejamento a longo prazo da revegetação para o fechamento de minas a céu aberto no Brasil. Revista Árvore, 25: 487-499.

Trajano E., 1987 - Fauna cavernicola brasileira: composição e caracterização preliminar. Revista Brasileira de Zoologia, 3 (8): 533-561.

https://doi.org/10.1590/S0101-81751986000400004
Trajano E. \& Moreira J.R.A., 1991 - Estudo da fauna de cavernas da Província Espeleológica Arenitica AltamiraItaituba. Revista Brasileira de Biologia, 51 (1): 13-29.

Trajano E. \& Gnaspini P., 1991 - Composição da fauna cavernícola brasileira, com uma análise preliminar da distribuição dos táxons. Revista Brasileira de Zoologia, 7 (3): 383-407.

https://doi.org/10.1590/S0101-81751990000300017

Trajano E., 1992 - Nota sobre os cavernicolas da Provincia Espeleológica do Bambui. Espeleo-Tema, 16: 95-101.

Trajano E. \& Bichuette M.E., 2009 - Diversity of Brazilian subterranean invertebrates, with a list of troglomorphic taxa. Subterranean Biology, 7: 1-16.

Weinstein P. \& Slaney D., 1995 - Invertebrate faunal survey of Rope Ladder Cave, Northern Queensland: a comparative study of sampling methods. Journal of the Australian Entomological Society, 34: 233-236. https://doi.org/10.1111/j.1440-6055.1995.tb01329.x

Wilson E.O., 1962 - The trinidad cave ant Erebomyrma (Spelaeomyrmex) urichi (Wheeler), with a comment on cavernicolous ants in general. Psyche, 69 (2): 62-72. https://doi.org/10.1155/1962/54863

Wilson E.O., 1976 - Which are the most prevalent ant genera? Studia Entomologica, 19: 187-200.

Wynne J.J. \& Voyles K.D., 2013 - Cave-dwelling arthropods and vertebrates of North Rim Grand Canyon, with notes on ecology and management. Western North American Naturalist, 74 (1): 1-17. https://doi.org/10.3398/064.074.0102

Wynne J.J., Howarth F.G., Sommer S. \& Dickson B.G., 2019 - Fifty years of cave arthropod sampling: techniques and best practices. International Journal of Speleology, 48 (1): 33-48. https://doi.org/10.5038/1827-806X.48.1.2231

Zepon T. \& Bichuette M.E., 2017 - Influence of substrate on the richness and composition of Neotropical cave fauna. Anais da Academia Brasileira de Ciências, 89 (3): 1615-1628.

https://doi.org/10.1590/0001-3765201720160452 